\title{
Schistosoma mansoni antigens alter activation markers and cytokine profile in lymphocytes of patients with asthma
}

\author{
Tarcísio Vila Verde Santana de Almeida a , Jamille Souza Fernandes a , Diego Mota Lopes ${ }^{a}$, \\ Lorena Santana Andrade ${ }^{a}$, Sérgio Costa Oliveira ${ }^{\mathrm{b}, \mathrm{c}}$, Edgar M. Carvalho ${ }^{\mathrm{a}, \mathrm{b}, \mathrm{d}}$, \\ Maria Ilma Araujo ${ }^{\mathrm{a}, \mathrm{b}, \mathrm{e}}$, Álvaro A. Cruz ${ }^{\mathrm{a}, \mathrm{f}}$, Luciana Santos Cardoso ${ }^{\mathrm{a}, \mathrm{b}, \mathrm{g}, *}$ \\ a Serviço de Imunologia, Hospital Universitário Professor Edgard Santos, Universidade Federal da Bahia, Salvador, Bahia, Brazil \\ b Instituto Nacional de Ciência e Tecnologia de Doenças Tropicais (INCT-DT/CNPq), Salvador, Bahia, Brazil \\ ${ }^{\mathrm{c}}$ Departamento de Bioquímica e Imunologia, Universidade Federal de Minas Gerias, Brazil \\ d Centro de Pesquisas Gonçalo Moniz, FIOCRUZ, Salvador, Bahia, Brazil \\ e Escola Baiana de Medicina e Saúde Pública, Salvador, Bahia, Brazil \\ ${ }^{\mathrm{f}}$ ProAR-Núcleo de Excelência em Asma, UFBA, Salvador, Bahia, Brazil \\ ${ }^{g}$ Departamento de Análises Clínicas e Toxicológicas, Faculdade de Farmácia, UFBA, Brazil
}

\section{A R T I C L E I N F O}

\section{Article history:}

Received 25 January 2016

Received in revised form

22 November 2016

Accepted 1 December 2016

Available online 5 December 2016

\section{Keywords:}

Asthma

Schistosoma mansoni antigens

Lymphocytes

$\operatorname{Sm} 29$

Sm29TSP-2

\begin{abstract}
A B S T R A C T
Asthma is a chronic disease characterized by airway inflammation, obstruction and hyperresponsiveness. Severe asthma affects a small proportion of subjects but results in most of the morbidity, costs and mortality associated with the disease. Studies have suggested that Schistosoma mansoni infection reduces the severity of asthma and prevent atopy.

Objective: We evaluated the ability of S. mansoni antigens, Sm29 and Sm29TSP-2 to modulate lymphocyte activation status in response to the allergen of the mite Dermatophagoides pteronyssinus (Der p 1$)$ in cell cultures of individuals with asthma.

Methods: Thirty four patients were enrolled in this study: seventeen patients with severe asthma (SA group), seventeen patients with mild asthma (MA group) and six controls with no asthma. Peripheral blood mononuclear cells (PBMC) were obtained and stimulated with Sm29 and Sm29TSP-2 in the presence or absence of Der 1 . The expression of surface markers and cytokines on lymphocytes was evaluated by flow cytometry and the levels of IL-10 in the culture supernatant were determined by ELISA.

Results: The addition of Sm29 and Sm29TSP-2 antigens to PBMC cultures from both groups of subjects with asthma stimulated with Der $p 1$ reduced the frequency of $\mathrm{CD} 4^{+} \mathrm{CD} 25^{\text {low }}$ cells whereas and increased frequency of $\mathrm{CD} 4^{+} \mathrm{CD} 25^{\text {high }}$ population was observed compared to unstimulated cultures. Moreover, cultures stimulated with Sm29TSP-2 showed a reduction in the frequency of T cells expressing CD69, IFN- $\gamma$, TNF and TGF- $\beta$ in the MA group and an increase in the frequency of CD4 ${ }^{+} \mathrm{TSLPR}^{+} \mathrm{T}$ cells in the SA group. The addition of Sm 29 to the cultures reduced the frequency of $C D 4^{+} \mathrm{CD} 69^{+}$and $\mathrm{CD} 4^{+} \mathrm{IL}-5^{+} \mathrm{T}$ cells in all asthmatic groups, and reduced the frequency of $\mathrm{CD} 4^{+} \mathrm{T}$ cells expressing IL-13 in the MA group. The cultures stimulated with Sm29 and Sm29TSP-2 showed an increase in the level of IL-10 in the supernatants.

Conclusion: These results suggest that the addition of Sm29 and Sm29TSP-2 to the cells cultures from subjects with asthma reduced cell activation markers and altered the cytokine production pattern in a way that can potentialy control the inflammatory response associated with asthma.
\end{abstract}

(C) 2016 Elsevier B.V. All rights reserved.

\section{Introduction}

Severe asthma affects approximately $5 \%$ to $10 \%$ of patients with asthma worldwide and is characterized by the persistence of symp-

\footnotetext{
* Corresponding author at: Serviço de Imunologia, Complexo Hospitalar Universitário Professor Edgard Santos, Universidade Federal da Bahia, Rua João das Botas s/n, Canela, 40110-160 Salvador, Bahia, Brazil.

E-mail addresses: lucianac@ufba.br, luciana.imuno@gmail.com (L.S. Cardoso).
}

toms, frequent exacerbations, reduced lung function and a need for high doses of inhaled corticosteroids (Antonicelli et al., 2004; Bousquet et al., 2010; Hekking et al., 2014; Moore et al., 2007; Von Bulow et al., 2014). The treatment of severe asthma is difficult, costly and bring the risk of adverse events. Only a small proportion of subjects with severe asthma reaches total control of symptoms and exacerbations, which affect significantly their quality of life and results in higher expenditures with the disease, often related to emergency room visits, hospitalizations and the use of other sort of 
Table 1

Characteristics of the study population.

\begin{tabular}{|c|c|c|c|c|}
\hline & Mild Asthma $(\mathrm{n}=17)$ & Severe Asthma $(\mathrm{n}=17)$ & Healthy Controls $(n=6)$ & $\mathrm{P}$ \\
\hline Age $(\text { years })^{\mathrm{a}}($ mean $\pm \mathrm{DP})$ & $38,8 \pm 14,3$ & $46,5 \pm 11,4$ & $43,5 \pm 13,3$ & $>0,05$ \\
\hline Female gender $\mathrm{n}(\%)^{\mathrm{b}}$ & $13(76,4)$ & $11(64,7)$ & $5(83,3)$ & $>0,05$ \\
\hline Positivity to the skin prick test to $\operatorname{Der} p 1 \mathrm{n}(\%)^{\mathrm{b}}$ & $4(23,5)$ & $6(35,2)$ & $0(0)^{c}$ & $<0,0001$ \\
\hline SWAP-specific IgE (mean \pm SD) & $0.12 \pm 0.03$ & $0.05 \pm 0.04$ & $0.14 \pm 0.07$ & $>0.05$ \\
\hline \multicolumn{5}{|l|}{ Cutoff IgE: 0.36.} \\
\hline \multicolumn{5}{|l|}{ a ANOVA. } \\
\hline \multicolumn{5}{|l|}{ b Chi-square. } \\
\hline
\end{tabular}

heath resources (Antonicelli et al., 2004; Franco et al., 2009; O'Neill et al., 2015; Santos et al., 2007).

In recent years, many studies have suggested that infection by helminths may modulate the allergic response in asthma, being associated to lower frequency of positive skin prick tests to aeroallergens, and a lower prevalence of atopy in general among individuals living in helminth-endemic areas (Alcantara-Neves et al., 2014; Araujo et al., 2000; Cooper et al., 2003; Hagel et al., 1993; Lynch et al., 1993; Lynch et al., 1987; Medeiros et al., 2004; Van den Biggelaar et al., 2001; Van den Biggelaar et al., 2000). Asthmatics individuals infected with Schistosoma mansoni have less severe asthma symptoms as compared to uninfected patients. Moreover, the anthelmintic treatment against $S$. mansoni led to a worsening of asthma symptoms and to an increase in allergenspecific serum IgE (Almeida et al., 2012; Campolina et al., 2013; Medeiros et al., 2003; Van den Biggelaar et al., 2004). Furthermore, infection with $S$. mansoni has been associated with a reduced Th2 response in vitro and in murine model with an increase in regulatory mechanisms that may be associated with the control of inflammation and improvement in asthma symptoms (Araujo et al., 2004; Oliveira et al., 2009; Smits et al., 2007).

Regulatory T cell activation have been one of the main hypotheses to explain the inverse relationship between allergy and $S$. mansoni infection (Layland et al., 2013; Van der Vlugt et al., 2012). The literature has described $\mathrm{CD}^{+} \mathrm{T}$ lymphocytes that do not express CD25 (CD25 ${ }^{\text {neg }}$ ) as young effector cells that are not yet activated, while those with a low expression of CD25 (CD25 low $)$ are considered activated responder $\mathrm{CD} 4^{+} \mathrm{T}$ cells (Baecher-Allan et al., 2001). CD4 ${ }^{+}$T cells with a high expression of CD25 (CD25 high $)$are associated with the suppression of the immune response and are, able to control the activation and proliferation of activated cells by cell-cell contact via costimulatory molecules such as CTLA- 4 and PD-1, or by the production of regulatory cytokines, such as IL-10 (Baecher-Allan et al., 2001; Gangi et al., 2005; Okita et al., 2009; Pontoux et al., 2002; Sojka et al., 2009; Uhlig et al., 2006).

The studies mentioned above provided support to further investigating the use of parasite antigens to down-modulate the inflammatory response observed in subjects with asthma. Studies have shown that chronic helminth infections, especially Schistosoma mansoni, possesses the ability to modulate the inflammatory response associated to both, Th1 (Bafica et al., 2011; Lima et al., 2013) and Th2 (Cardoso et al., 2012; Cardoso et al., 2010; Cardoso et al., 2006a,b; Pacifico et al., 2009) immune-mediated diseases. These findings have provided the rationale for the use of recombinant $S$. mansoni proteins in in vitro studies with cells from patients with asthma in an attempt to modulate the response associated with inflammatory process. Studies have shown that Sm29 and SmTSP-2 antigens are secreted by the membrane and/or tegument of the S. mansoni adult worm (Cardoso et al., 2006a,b; Tran et al., 2006). Proteins secreted or localized on the surface of Schistosoma spp., which are in intimate contact with host tissues, might be more effective in triggering immunoregulatory processes (Simpson et al., 1990). The Sm29 is a membrane-bound glycoprotein located on the tegument of the adult worm and lung stage schistosomula (Cardoso et al., 2006a,b). SmTSP-2 is a recombinant protein (tetraspanin) from S. mansoni tegument (Tran et al., 2006). These antigens have been evaluated by our group regarding their potential to downmodulate inflammatory cytokines and to induces IL-10 production in vitro in PBMC from individuals with cutaneous leishmaniasis, HTLV-1 infection and asthma (Bafica et al., 2011; Cardoso et al., 2010; Lima et al., 2013). Thus, the identification of parasite antigens with the potential to prevent or attenuate the inflammatory response associated with asthma represents a promising strategy for an alternative intervention to control this chronic illness.

\section{Materials and methods}

\subsection{Features of the studied subjects}

In this study, we recruited 17 consecutive patients with severe asthma followed up for over one year in the Program for the Control of Asthma of Bahia (ProAR), a reference center for severe asthma in Salvador, Bahia, Brazil, 17 patients with mild asthma and 6 health controls (HC), recruited consecutively from the same communities patients with severe asthma live, invited to volunteer by public advertisement in health facilities and public transportation. Subjects were recruited from January 2013 until July 2015 and the blood samples processed immediately upon collection. Subjects were not included if they had an exacerbation in the last month regardless of using oral corticosteroids or not. At the time of blood samples collection all subjects with severe asthma were treated with a combination of medium to high dose of inhaled corticosteroids (800mcg to 1600 of budesonide or equivalent) and long acting beta 2 agonist. Those with mild asthma were not receiving inhaled corticosteroids. Individuals with severe asthma were identified as having untreated severe asthma at enrollment in ProAR (from 2003), according to the NIH Guidelines for Asthma (NIHNHBLI. Guidelines for the Diagnosis and Management of Asthma, 1997) and a WHO consultation on severe asthma (Bousquet et al., 2010). In brief, they had any one of the following: (i) symptoms daily, continuous; (ii) activities limited daily (symptoms with minor efforts); (iii) nocturnal symptoms over 2 times a week; (iv) use of bronchodilators $\geq 2$ times a day; (v) Peak Expiratory Flow (PEF) or Forced Expiratory Volume in one second $\left(\mathrm{FEV}_{1}\right):<60 \%$ of predict. Subjects with mild asthma were recruited on the basis of their history of asthma, having their diagnosis validated by a doctor in the research facility. We did not include in this study current smokers individuals and those with a positive serology for Chagas disease, HIV, HTLV-1, or hepatitis virus types B and C, all of which are conditions that could interfere with the immunological response. All participants were submitted to skin prick test to Dermatophagoides pteronyssinus antigen 1 (Der $p 1)$ and a panel of the most common aeroallergens including other house dust mites, coacoroach, molds, cat, dog and grass. To rule out the effect of $S$. mansoni previous exposure in immunological assays, we also excluded individuals who had a positive $S$. mansoni infection or exposure to this parasite any time in his/her life. In the urban area 
of Salvador da Bahia there is no report of Schistosoma infection in the last decades.

Furthermore, we measured the levels of serum-specific IgE to $S$. mansoni soluble adult worm antigen (SWAP) and performed parasitological assays by Hoffman et al. technique (Hoffman et al., 1934). There was no significant difference in the mean age, gender and levels of serum-specific IgE to SWAP among groups evaluated. Additionally, there were no significant differences regarding the response to skin prick test (SPT) to Der $p 1$ between asthmatics. The HC group was negative to the SPT to Der $p 1$ (Table 1). All individuals were negative for $S$. mansoni infection by parasitological exams (not shown).

\subsection{Ethical statement}

The Ethics Committee of Maternidade Climério de Oliveira, Federal University of Bahia (License Number: 095/2009) approved the present study. Written informed consent was obtained from all patients and controls. All participants who had complaints of asthma and allergies were properly oriented regarding environmental control, prescribed the medication required and referred to the most convenient health facility.

\subsection{SWAP-specific IgE measurements in human serum}

Levels of SWAP-specific IgE were measured in serum from all studied individuals using an indirect ELISA technique, as previously described (Figueiredo et al., 2012; Souza-Atta et al., 1999).

\subsection{Cell culture and flow cytometry assays}

Peripheral blood mononuclear cells (PBMCs) were isolated using Ficoll-Hypaque gradient sedimentation and adjusted to a concentration of $3 \times 10^{5} / \mathrm{mL}$ in RPMI 1640 medium containing $10 \%$ normal human serum ( $A B$ positive and heat inactivated), $100 \mathrm{U} / \mathrm{mL}$ of penicillin, $100 \mathrm{mg} / \mathrm{mL}$ of streptomycin, $2 \mathrm{mmol} / \mathrm{L}$ of L-glutamine, and $30 \mathrm{mmol} / \mathrm{L}$ of HEPES (all from Life Technologies GIBCO, BRL, Gaithersburg, MS). Cells were cultured in vitro either stimulated with $10 \mu \mathrm{g} / \mathrm{mL}$ of the S. mansoni antigens Sm29 and Sm29TSP-2 in the presence or absence of Der 11 (Cosmo Bio, LTD.; Tokyo, Japan) at the concentration of $5 \mu \mathrm{g} / \mathrm{mL}$ for $48 \mathrm{~h}$ at $37^{\circ} \mathrm{C}$ in an atmosphere containing $5 \% \mathrm{CO}_{2}$. After incubation, supernatants were harvested for IL-10 measurement by ELISA using commercially available kits (R\&D Systems, Inc.), and the cells were stained for flow cytometry as described below.

During the last $4 \mathrm{~h}$ of culture, Brefeldin A $(10 \mu \mathrm{g} / \mathrm{mL}$; Sigma, St. Louis, MO), which impairs protein secretion by the Golgi complex, was added to the cultures. Cells were stained with fluorescently conjugated mouse anti-human monoclonal antibodies against human CD3 (clone OKT3, eBioscience), CD4 (clone OKT4, eBioscience), CD25 (clone BC96, eBioscience), CD28 (clone CD28.2, eBioscience), CD69 (clone L78, Becton Dickinson), CTLA-4 (clone 14D3, eBioscience) and TSLPR (clone 1A6, eBioscience), and then analyzed for 100000 events per sample using a flow cytometer (FACSCanto, Becton Dickinson, San Jose, CA). Limits for the quadrant markers were set based on negative populations and controls isotype (data not shown).

Intracellular staining was performed with a PE-labeled monoclonal antibody against human FoxP3 (clone 236A/E7, eBioscience), IL-10 (clone JES3-19F1, eBioscience), TGF- $\beta$ (clone TW4-2F8, eBioscience), IFN- $\gamma$ (clone GZ-4, eBioscience), TNF (clone MAb11, eBioscience), IL-17A (clone eBio64DEC17, eBioscience), IL-13 (PVM13-1, eBioscience) and IL-5 (clone JES1-39D10, eBioscience). The Clone TW4-2F8 (eBioscience) evaluated detects LAP/pro-TGF$\beta 1$.
The frequency of positive cells was analyzed using the program FlowJo $^{\mathrm{TM}}$ (Tree Star, USA). The lymphocyte region was defined by nonspecific fluorescence with forward scatter (FSC) and side scatter (SSC) used to indicate cell size and granularity, respectively. The cells were also gated based on their expression of CD3 and CD4 (Fig. 1A). Fig. 1B and C shows a representative gate strategy to analyse the different $\mathrm{CD} 4^{+} \mathrm{CD} 25^{+}$and $\mathrm{CD} 4^{+} \mathrm{CD} 69^{+} \mathrm{T}$ cell populations, respectively.

\subsection{Antigen stimulation}

The Schistosoma mansoni tegument antigens Sm29 and Sm29TSP-2, used in this study were provided by Dr. Sérgio C. Oliveira from the Institute of Biological Science, Department of Biochemistry and Immunology, UFMG, Brazil. The recombinant proteins were cloned in E. coli (Cardoso et al., 2006a,b; Pinheiro et al., 2014) and were tested for the presence of lipopolysaccharide (LPS) using a commercially available LAL Chromogenic Kit (CAMBREX).The level of LPS was below the detection limit (data not shown).

\subsection{Statistical analysis and sample size}

Statistical analysis and graphical representation were performed using Graphpad PRISM 5.0 software (La Jolla, CA, USA). Comparisons among age of groups were performed using ANOVA and for immunological assays we used Kruskal Wallis test with Dunns pos-test. Comparisons among gender and positivity skin prick test and SWAP-specific IgE were performed using chi-square test. All statistical tests were two-tailed and statistical significance was established at the 95 percent confidence interval. $P$-value $<0.05$ were considered significant. The sample size calculation was performed based on the frequency of IL-10 expression in $\mathrm{CD}^{+} \mathrm{CD} 25^{+} \mathrm{T}$ cells from healthy subjects with mild asthma stimulated with Der $p 1$ plus Sm29 (Cardoso et al., 2011). A minimum size of 16 patients per group would be sufficient to detect significant differences.

\section{Results}

\subsection{Effect of S. mansoni antigens on the expression of CD25 molecules on $C D 4^{+}$T lymphocytes}

Different degrees of CD25 expression on $\mathrm{CD}^{+} \mathrm{T}$ lymphocytes have been associated with either activation or regulatory profile in these cells. Therefore, we decided to analyze the expression of this molecule in T cell populations from subjects with mild asthma (MA) and severe asthma (SA) after the addition of $S$. mansoni antigens to the cultures in the presence of Der p1 antigen.

In the MA group, there was a reduction in the frequency of $\mathrm{CD}^{+} \mathrm{CD} 25^{\text {low }} \mathrm{T}$ cells in cultures stimulated with $\mathrm{Der}$ $p 1+\operatorname{Sm} 29$ [ median $=2.68 \%(\min -\max =1.16 \%-10.50 \%) ; \mathrm{p}<0.05$ ], Der p1 + Sm29TSP-2 [2.89\% (0.76\%-9.73\%); p <0.05], Sm29 [1.12\% $(0.49 \%-3.64 \%) \quad \mathrm{p}<0.001]$ or Sm29TSP-2 [1.08\% (0.53\%-2.09\%); $\mathrm{p}<0.001$ ] compared to the frequency in cultures stimulated with Der p1 alone [3.93\% (1.30\%-11.60\%); Fig. 2A]. Additionally, we observed a lower frequency of $\mathrm{CD} 4^{+} \mathrm{CD} 25^{\text {low }} \mathrm{T}$ cells in cultures without stimulation (WS cultures) [0.97\% (0.34\%-3.82\%)] than in those stimulated with Der $p 1(\mathrm{p}<0.001)$, Der $p 1+\operatorname{Sm} 29(\mathrm{p}<0.001)$, Der $p 1+\operatorname{Sm} 29 T S P-2(p<0.001), \operatorname{Sm} 29(\mathrm{p}<0.05)$ or Sm29TSP-2 $(\mathrm{p}<0.05$; Fig. 2A).

In the SA group we found similar results with a reduction in the frequency of $\mathrm{CD} 4^{+} \mathrm{CD} 25^{\text {low }} \mathrm{T}$ cells in cultures stimulated with Der p1 + Sm29 [2.77\% (0.90\%-10.60\%); p < 0.05], Der p1 + Sm29TSP2 [2.63\% (1.07\%-9.92\%); p <0.05], Sm29 [1.78\% (0.44\%-3.78\%) $\mathrm{p}<0.001]$ or Sm29TSP-2 [1.36\%(0.97\%-2.46\%); $\mathrm{p}<0.001]$ compared 
A
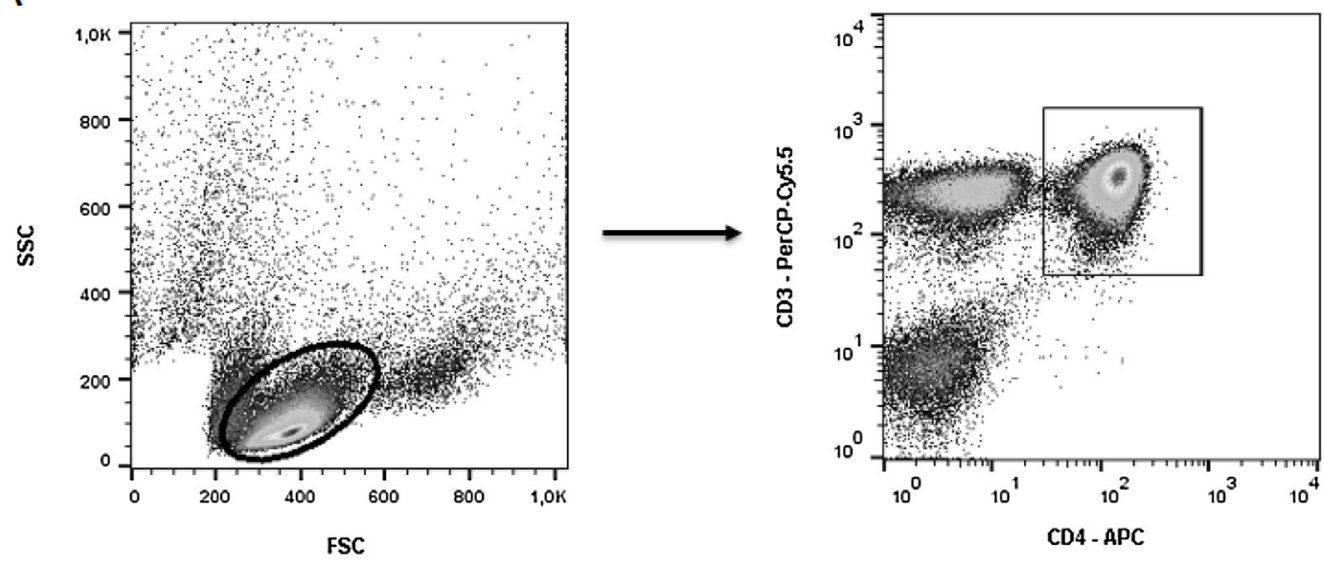

$B$
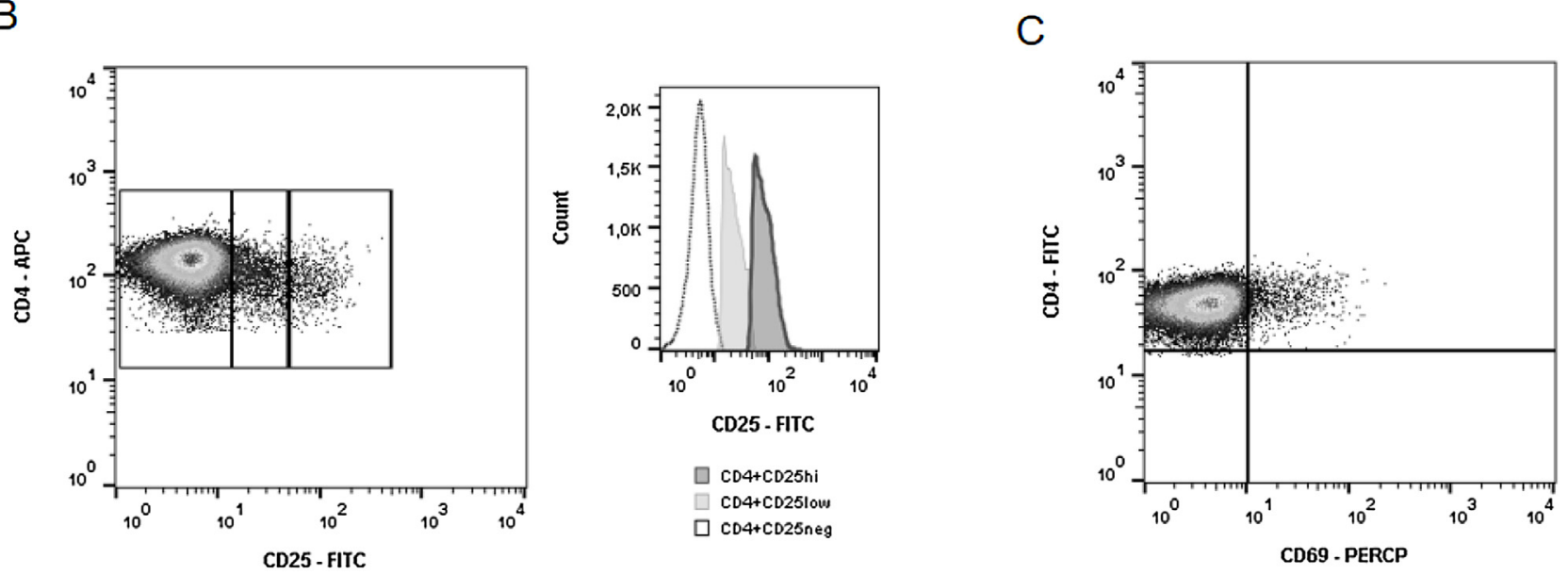

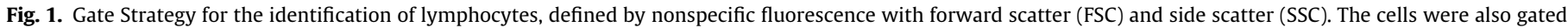
based on their expression of CD3 and CD4 (A). Representative gate strategy to analyse the different CD4 $4^{+} \mathrm{CD} 25^{+}$and $\mathrm{CD} 4{ }^{+} \mathrm{CD} 69^{+} \mathrm{T}$ cell populations (B and C, respectively).

to the frequency in cultures stimulated with Der $p 1$ alone [3.93\% (1.30\%-11.60\%); Fig. 2B]. We also observed a lower frequency of $\mathrm{CD}^{+} \mathrm{CD}^{2} 5^{\text {low }} \mathrm{T}$ cells in cultures without stimulation $[0.96 \%$ $(0.29 \%-3.04 \%)]$ than in those stimulated with Der 1 ( $\mathrm{p}<0.001), \operatorname{Der}$ $p 1+\operatorname{Sm} 29(\mathrm{p}<0.001)$, with Der $p 1+\operatorname{Sm} 29 \mathrm{TSP}-2(\mathrm{p}<0.001), \operatorname{Sm} 29$ $(\mathrm{p}<0.05)$ or Sm29TSP-2 ( $<<0.05$; Fig. $2 \mathrm{~B})$.

In the HC group the addition of Sm29 or Sm29TSP-2 to the cultures stimulated with Der $p 1$ did not alter the frequency of $\mathrm{CD} 4{ }^{+} \mathrm{CD} 25^{\text {low }} \mathrm{T}$ lymphocytes compared to the frequency in cultures stimulated with Der $p 1$ alone (Fig. 2C). We observed a lower frequency of $\mathrm{CD} 4^{+} \mathrm{CD} 25^{\text {low }} \mathrm{T}$ cells in WS cultures [1.47 (0.45-2.68)] compared to the cultures stimulated with Der $p 1$ alone [3.30 (1.76-9.16), p<0.05; Fig. 2C].

When we analyzed the $\mathrm{CD} 4^{+} \mathrm{CD} 25^{\mathrm{hi}} \mathrm{T}$ cells population in the MA group (Fig. 2D), we found a higher frequency of these cells in cultures stimulated with Der $p 1+\operatorname{Sm} 29$ [0.97\% (0.18\%-1.83\%); $\mathrm{p}<0.001]$, Der p1+Sm29TSP-2 [0.96\% (0.39\%-1.68\%); p<0.001], Sm29 [0.68\% (0.29\%-1.27\%); p<0.01], Sm29TSP-2 [0.73\% (0.22\%-1.20\%); $<<0.01]$ or Der 1 alone [0.76\% $(0.28 \%-1.4 \%) ; \mathrm{p}<0.001]$ compared to the frequency in WS cultures $[0.28 \%(0.13 \%-0.78 \%)]$.

Similar to results from the MA group, in the SA group (Fig. 2E) there was an increase in the frequency of $\mathrm{CD} 4^{+} \mathrm{CD} 25^{\text {hi }} \mathrm{T}$ cells in cultures stimulated with Der p1+Sm29 [0.97\% (0.44\%-2.05\%); $\mathrm{p}<0.001]$, Der p1 + Sm29TSP-2 [0.79\% (0.44\%-1.94\%); $<<0.001]$ or Der 1 alone [0.64\% (0.36\%-1.45\%); $\mathrm{p}<0.001]$ compared to the frequency in WS cultures [0.32\% (0.07\%-0.68\%)]. An increase in the population of $\mathrm{CD} 4{ }^{+} \mathrm{CD} 25^{\mathrm{hi}} \mathrm{T}$ lymphocytes was also observed in cul- tures stimulated with $\operatorname{Sm} 29$ [0.70\% $(0.26 \%-1.66 \%) ; \mathrm{p}<0.001]$ or Sm29TSP-2 [0.63\% (0.26\%-1.06\%); $\mathrm{p}<0.01$ ] compared to the frequency in WS cultures.

In the $\mathrm{HC}$ group there was a higher frequency of $\mathrm{CD} 4^{+} \mathrm{CD} 25^{\mathrm{hi}}$ cells in cultures stimulated with Der $p 1+\operatorname{Sm} 29[0.75 \%$ (0.54\%-1.12\%)] with Der p 1 + Sm29TSP-2 [0.76\% (064\%-1.31\%)] and Der $p 1$ [0.65\% (0.46\%-0.98\%)] compared to the frequency in WS cultures [0.39\% (0.24\%-0.47\%); $<<0.01$; Fig. $2 \mathrm{~F}]$.

The MA group showed a higher frequency of $\mathrm{CD} 4^{+} \mathrm{CD} 25^{\text {neg }}$ $\mathrm{T}$ cells in WS cultures [98.70\% (95.70\%-99.50\%)] compared to the frequency in cultures stimulated with Der $p 1$ [95.35\% (87.30\%-98.40\%); p < 0.001], Der p1+Sm29 [96.50\% (88.40\%-98.60\%); $\mathrm{p}<0.001]$ or Der $p 1+\operatorname{Sm} 29 \mathrm{TSP}-2$ [96.30\% (89.40\%-98.90\%); $\mathrm{p}<0.01$; Fig. 2G]. An increase in the frequency of $\mathrm{CD} 4^{+} \mathrm{CD} 25^{\text {neg }} \mathrm{T}$ cells was also observed in cultures stimulated with Sm29 [98.30\% (95.70\%-99.20\%)] or Sm29TSP-2 [98.30\% $(97.20 \%-99.20 \%)]$ compared to the frequency in those stimulated with Der $p 1$ ( $\mathrm{p}<0.001$; Fig. 2G).

In the SA group, the addition of Sm29TSP-2 to the cultures stimulated with Der $p 1$ led to an increase in the frequency of CD4 ${ }^{+} C D 25^{\text {neg }} T$ cells [96.10 (89.30\%-98.10\%); $\left.\mathrm{p}<0.05\right]$ compared to the frequency in those stimulated with Der $p 1$ alone $[95.40 \%$ (85.40\%-96.80\%); $\mathrm{p}<0.001$ ]. This increase was also observed in cultures stimulated with Sm29 [97.40\% (95.30\%-99.10\%)] or with Sm29TSP-2 [97.95\% (96.20\%-98.60\%)] compared those stimulated with Der $p 1$ ( $\mathrm{p}<0.001$; Fig. $2 \mathrm{H})$.

There was no significant difference in the frequency of $\mathrm{CD} 4^{+} \mathrm{CD} 25^{\text {neg }} \mathrm{T}$ cells in cultures stimulated with Der $p 1$ in the 

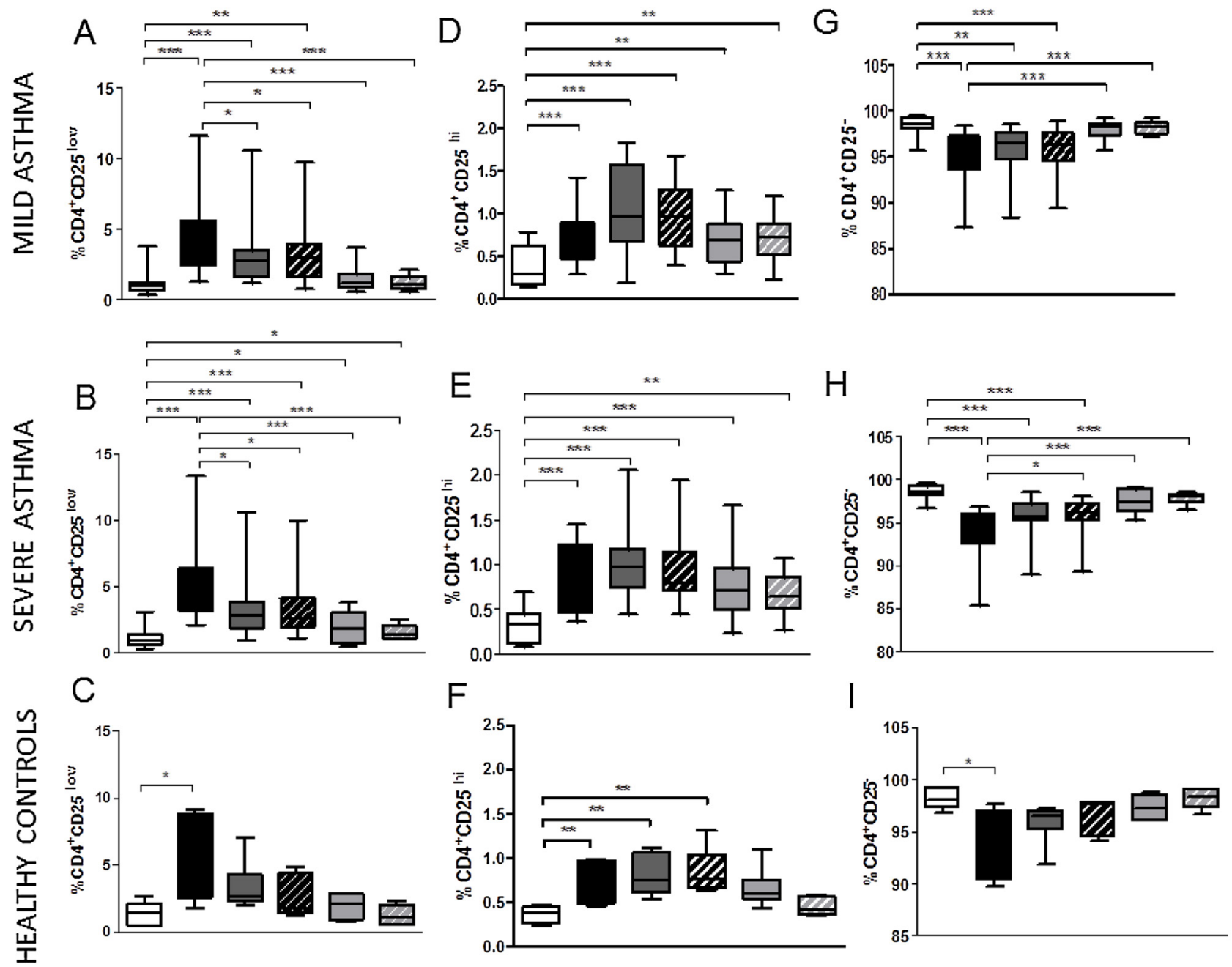

WS Der $p 1 \square$ Der $p 1+S m 29$

Der p1+Sm29TSP-2

$\operatorname{Sm} 29$

Sm29TSP-2

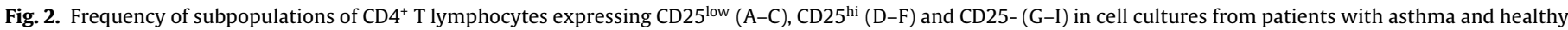

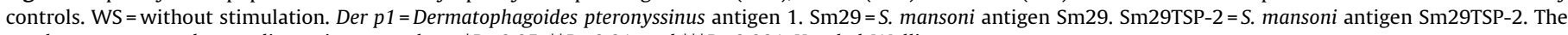
results are expressed as median, min-max values. ${ }^{*} P<0.05$, ${ }^{* *} P<0.01$, and ${ }^{* * *} P<0.001$, Kruskal-Wallis test.

presence or absence of $S$. mansoni antigens in cultures from HC group (Fig. 2I). In this group we observed a higher frequency of $\mathrm{CD}^{+} \mathrm{CD} 25^{\text {neg }} \mathrm{T}$ cells in WS cultures [98.00 (96.80-99.20)] compared to the frequency in cultures stimulated with Der $p 1$ [95.80 (89.70-97.70), p < 0.05; Fig. 2I]

Since the expression of transcription factor Foxp3 is essential to the regulatory function of $\mathrm{T} C \mathrm{CD} 4^{+} \mathrm{CD} 25^{\mathrm{hi}}$ cell population, we decided to evaluate the expression of the molecule in this group of cells (Fig. 3). We did not observe significant difference in the frequency of $\mathrm{T} \mathrm{CD} 4^{+} \mathrm{CD} 25^{+}$cell expressing Foxp3 in the cultures stimulated with Der $p 1$ in the presence or absence of $S$. mansoni antigens in all evaluated groups (Fig. $3 \mathrm{~A}-\mathrm{C}$ ).

\subsection{Activation $C D 28$ and $C D 69$ molecules expressed by $C D 4^{+} T$ lymphocytes in response to the $\mathrm{S}$. mansoni antigens}

The frequency of activation molecules CD28 and CD69 in CD4 ${ }^{+} \mathrm{T}$ lymphocytes in PBMC cultures from asthmatic subjects in response to the $S$. mansoni antigens was evaluated. There were no significant difference in the frequency of $\mathrm{CD} 4^{+} \mathrm{CD} 28^{+}$cells in the MA group in the presence of Sm29 and Sm29TSP-2 antigens ( $>$ > 0.05; Fig. 4A). On the other hand, in the SA group we observed a lower frequency of $\mathrm{CD} 4^{+} \mathrm{CD} 28^{+} \mathrm{T}$ cells in cultures stimulated with
Sm29TSP-2 [93.60\% (74.60\%-98.50\%)], compared to the frequency in WS cultures [96.25\% (82.60\%-98.90\%); $\mathrm{p}<0.05$; Fig. 4B].

We observed a decrease in the frequency of cells expressing CD69 in PBMC cultures from the MA group that were stimulated with Der p1+Sm29 [0.46\% (0.09\%-1.7\%); p < 0.05], with Der $P 1+$ Sm29TSP-2 [0.46\% (0.13\%-1.56\%); $\mathrm{p}<0.01]$, compared to the frequency in cultures stimulated with $\operatorname{Der} p 1$ [1.48\% (0.04\%-4.91\%); Fig. 4D]. In this same group, cultures stimulated with Sm29 [0.37\% (0.12\%-2.32\%); $\mathrm{p}<0.01$ ], or with Sm29TSP-2 [0.35\% (0.12\%-1.84\%); $\mathrm{p}<0.01$ ] showed a decrease in the frequency of $\mathrm{CD} 4^{+} \mathrm{CD} 69^{+} \mathrm{T}$ cells, compared to the frequency in cultures stimulated with Der $p 1$ alone [0.41\% (0.04\%-1.29\%); Fig. 4D].

In the SA group there was also a reduction in the frequency of $\mathrm{CD}^{+} \mathrm{CD}_{69}{ }^{+} \mathrm{T}$ cells in cultures stimulated with Der $p 1+\operatorname{Sm} 29$ [0.72\% $(0.38 \%-1.6 \%) ; \mathrm{p}<0.05]$, compared to the frequency in cultures stimulated with Der $p 1$ alone [1.27\% (0.38\%-3.41\%); Fig. 4E]. In cultures stimulated with Sm29 [0.52\% (0.17\%-2.15\%); $\mathrm{p}<0.01]$ or Sm29TSP-2 [0.36\% (0.15\%-1.69\%); $<<0.001]$ and in WS cultures [0.29\% $(0.07 \%-2.24 \%) ; \mathrm{p}<0.001]$, there was also a reduction in the frequency of $\mathrm{CD}^{+} \mathrm{CD} 69^{+} \mathrm{T}$ cells, compared to the frequency in cultures stimulated with Der $p 1$. A lower frequency of $\mathrm{CD} 4^{+} \mathrm{CD} 69^{+}$ $\mathrm{T}$ cells was also observed in the cultures stimulated with Der $p 1+\operatorname{Sm} 29(\mathrm{p}<0.01)$ and Der $1+$ Sm29TSP-2 [0.81\% (0.17\%-3.16\%) 


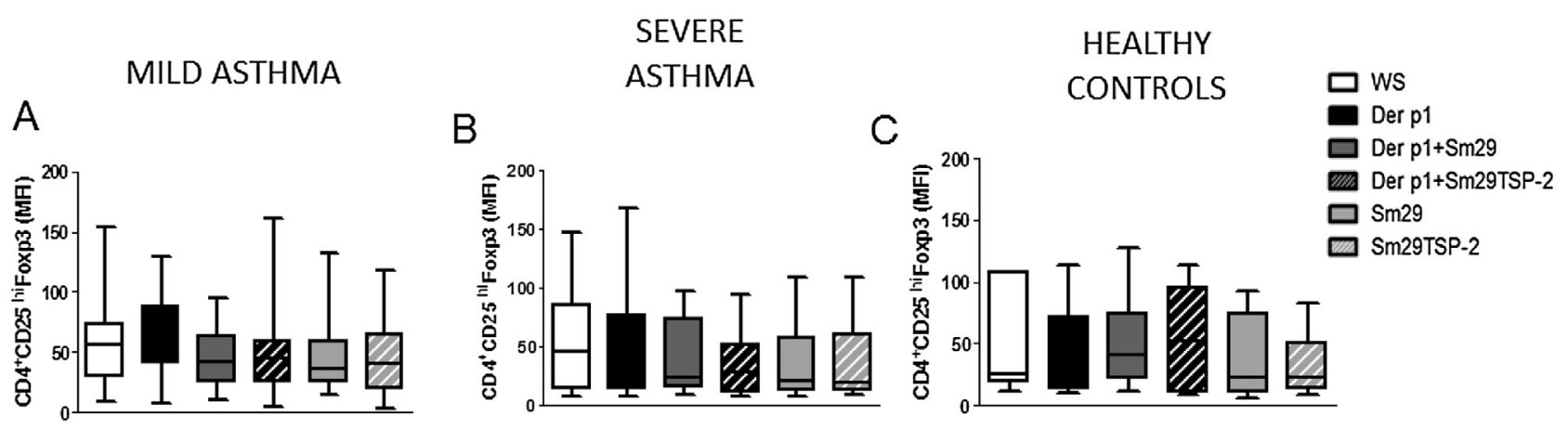

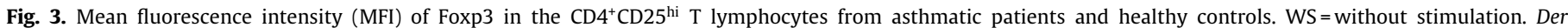

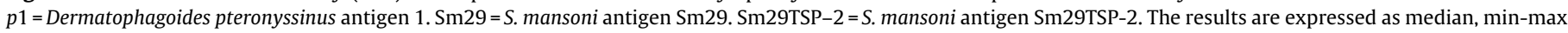
values.
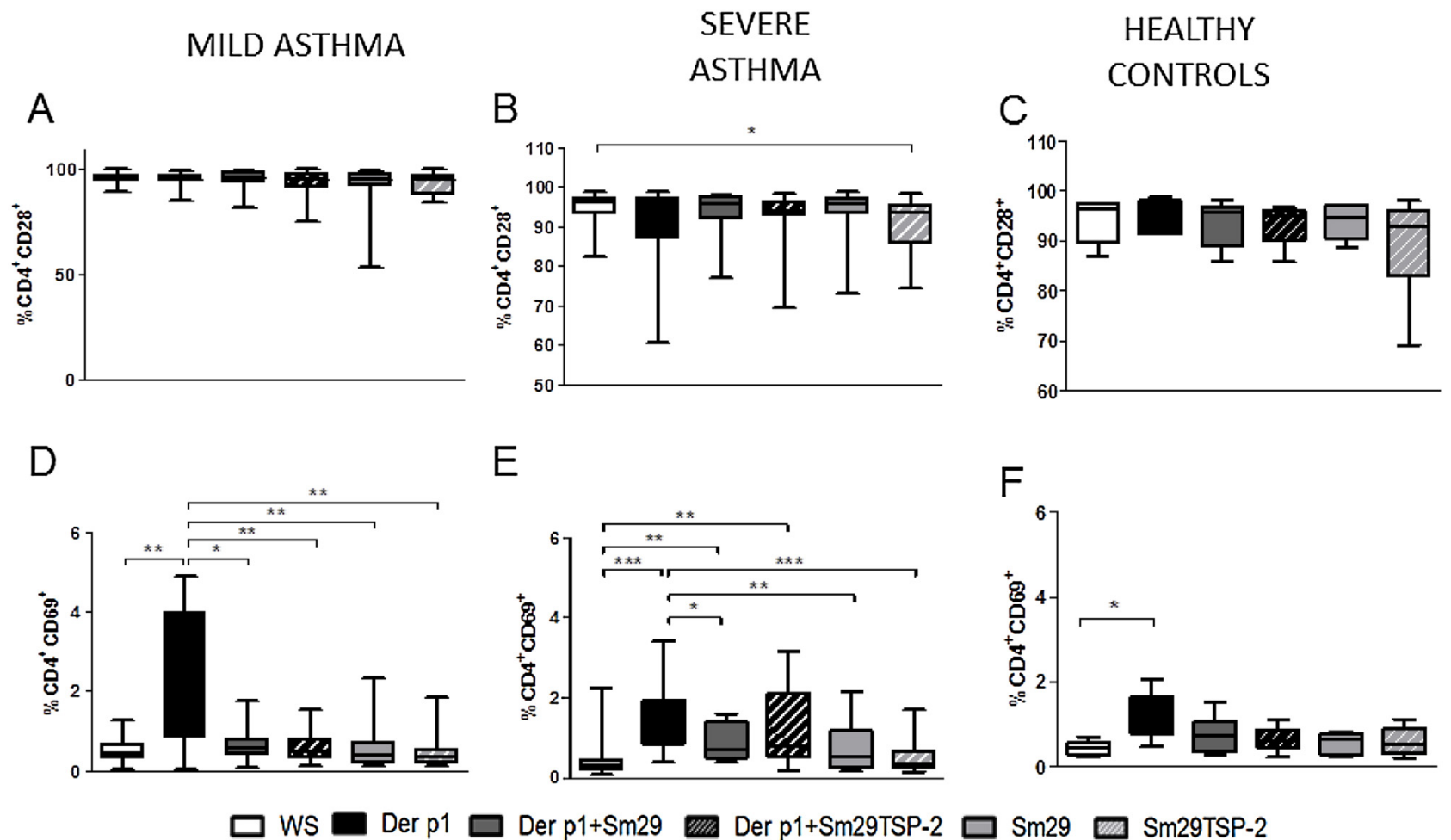

E
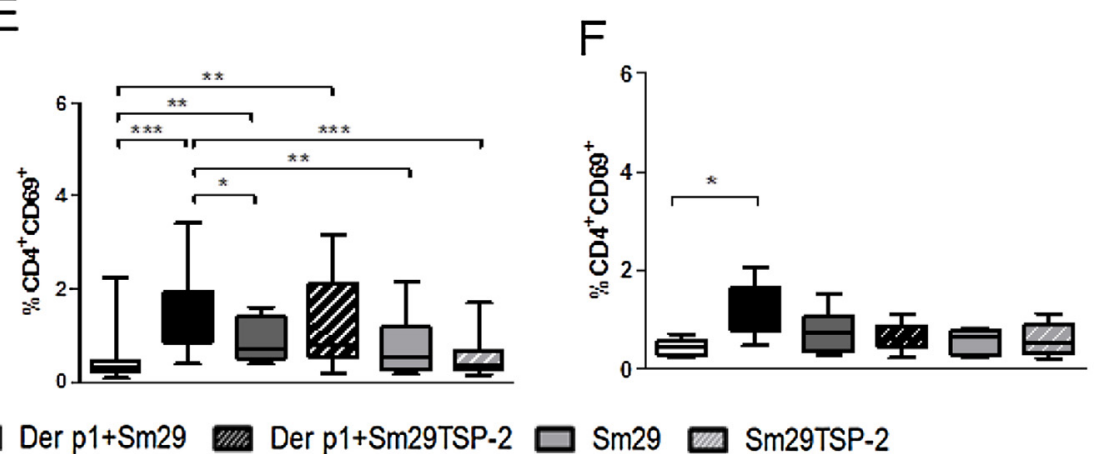

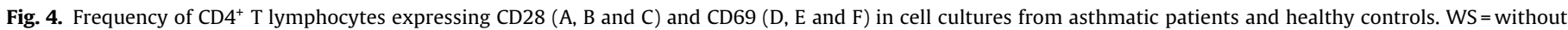

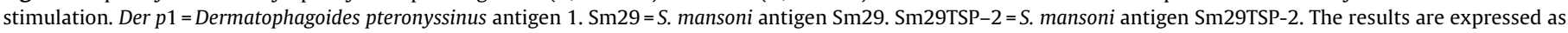
median, min-max values. ${ }^{*} P<0.05$, ${ }^{* *} P<0.01$, and ${ }^{* * *} P<0.001$, Kruskal-Wallis test.

$\mathrm{p}<0.01$ ], compared to the frequency in those stimulated with Der $p 1$ (Fig. 4E).

In the MA group the frequency of $\mathrm{CD} 4^{+} \mathrm{T}$ cells expressing $\mathrm{CD} 69$ in the cultures stimulated with Der $p 1+$ Sm29TSP-2 was higher [0.46 (0.13-1.56)] than in those observed in SA group [0.72 (0.38-1.60), $\mathrm{p}<0.05$; Table 3], while there was no significant difference in the frequency of $\mathrm{CD} 4^{+} \mathrm{T}$ cells expressing CD28 (Fig. 4C) or CD69 (Fig. 4F) in cultures stimulated with $\operatorname{Der} p 1$ in the presence or absence of $S$. mansoni antigens in cultures from HC group.

\subsection{Reduced expression of IFN- $\gamma$ or TNF by $C D 4^{+}$T lymphocytes after the addition of Sm29 and Sm29TSP-2 to cultures from asthmatic patients}

The expression of intracellular cytokines TNF, IFN- $\gamma$ and IL$17 \mathrm{~A}$ by $\mathrm{CD}^{+}{ }^{+} \mathrm{T}$ lymphocytes was also evaluated in this study, because these cytokines have been associated with a worsen- ing of the inflammatory process in asthma. A lower frequency of $\mathrm{CD}^{+} \mathrm{TNF}^{+} \mathrm{T}$ cells was observed in the cultures stimulated with Der 1 + Sm29TSP-2 [0.09\% (0.02\%-0.87\%); $\mathrm{p}<0.05]$ or Sm29TSP2 [0.09\% (0.04\%-0.73\%); $\mathrm{p}<0.01]$ and in WS cultures $[0.13 \%$ $(0.01 \%-0.73 \%) ; \mathrm{p}<0.05]$, compared to the frequency in cultures stimulated with Der $p 1$ alone [0.20\% (0.05\%-0.93\%); Table 2].

There was a reduction in the frequency of $\mathrm{CD} 4^{+}$IFN $-\gamma^{+}$T cells in the MA group in cultures stimulated with Der $p 1+\operatorname{Sm} 29 \mathrm{TSP}-2$ [0.21\% (0.03\%-1.38\%); $\mathrm{p}<0.05]$, compared to the frequency in cultures stimulated with Der $p 1$ alone [0.32\% (0.10\%-1.38\%); Table 2]. In cultures stimulated with $\operatorname{Sm} 29$ [0.21\%(0.06\%-0.70\%); $<<0.05]$ or Sm29TSP-2 [0.18\% (0.08\%-1.51\%); $<<0.05]$, there was also a reduction in the expression of this cytokine, compared to the expression in cultures stimulated with Der $p 1$ (Table 2).

There was no significant difference in the frequency of $\mathrm{CD} 4^{+} \mathrm{T}$ cells expressing IL-17A in cultures stimulated with Der $p 1$ in the presence or absence of $S$. mansoni antigens in cultures from either 
Table 2

Frequency of CD4+ $\mathrm{T}$ lymphocytes expressing TNF, IFN- $\gamma$, IL-17A, IL-5, IL-13, TSLPR, CTLA-4, IL-10 and TGF- $\beta$ in cell cultures from asthmatics patients.

\begin{tabular}{|c|c|c|c|c|c|c|c|c|c|c|c|c|}
\hline & \multicolumn{6}{|l|}{ MILD Asthma } & \multicolumn{6}{|l|}{ SEVERE Asthma } \\
\hline & Ws & Der $p 1$ & $\operatorname{Der} p 1+\operatorname{Sm} 29$ & Der $p 1+$ Sm29TSP-2 & $\mathrm{Sm} 29$ & Sm29TSP-2 & Ws & Der $p 1$ & Der $p 1+\operatorname{Sm} 29$ & Der $p 1+$ Sm29TSP- 2 & $\operatorname{Sm} 29$ & Sm29TSP-2 \\
\hline $\mathrm{CD}^{+}{ }^{+} \mathrm{TN}$ & $0.13(0.02-0.73)$ & $0.20(0.06-0.93)^{\dagger}$ & $0.15(0.04-0.89)$ & $0.10(0.02-0.87)^{*}$ & $0.12(0.05-0.4$ & $0.09(0.04-0.73)^{* *}$ & $0.14(0.06-1.97)$ & $0.16(0.05-2.96)$ & $0.19(0.04-0.36)$ & $0.16(0.07-0.28)$ & $0.12(0.02-0.85)$ & $0.16(0.07-0.74)$ \\
\hline & & $0.32(0.10-1.38)$ & & & & $0.18(0.08-1.51)^{*}$ & & $3-1.24)$ & & & & \\
\hline & 7) & $-1.49)$ & 44) & 3) & $0.16(0$ & $0.11(\mathrm{C} r(\mathrm{r})$ & $2-1.28)$ & $22-2.28)$ & 0.21 & 3) & 46) & 5) \\
\hline $\mathrm{CD}$ & $-1.79)$ & $(0.07-2.35)$ & $4-1.36)$ & $4(0.02-1.64)$ & $0.19(0.02-1.21)^{*}$ & $0.22(0.03-0.84)$ & $7-1.47)$ & 02 & $5-1.52)$ & 3) & $0.11(0.04-0.53)^{*}$ & $16(0.01-0.35)$ \\
\hline $\mathrm{CD}^{+} \mathrm{IL}^{+}-13^{+}(\%)$ & $0.93(0.07-2,65)$ & $0.78(0.06-2.82)$ & $0.78(0.13-1.86)$ & $1.07(0.02-2.07)$ & $0.69(0.01-1.72)$ & $0.42(0.01-0.90)$ & $(0.03-2.77)$ & $0.45(0.05-2.19)$ & $0.43(0.08-2.86)$ & $0.66(0.09-3.00)$ & $0.19(0.05-2.11)^{*}$ & $37(0.05-2.46)$ \\
\hline $\mathrm{CD}^{+} \mathrm{TSLPR}^{+}(\%)$ & $0.49(0.09-0.78)$ & $0.36(0.04-4.31)$ & & & & & & & & $0.62(0.12-1.52)^{* \dagger}$ & $0.23(0.13-1.84)$ & $0.18(0.07-0.92)$ \\
\hline $\mathrm{CD}_{4}^{+} \mathrm{CTLA}_{-4}^{+}(\%)$ & 1.35 & & 2. & & 1.6 & 1.5 & 1) & 0.5 & $1.45(0.15$ & $1.30(0.1$ & $-5.16)$ & $1.36(0.20-4.62)$ \\
\hline $\mathrm{CD}^{+} \mathrm{IL}-10^{+}(\%)$ & $0.43(0.04-1.78)$ & $0.47(0.04-2$ & $0.58(0.04-3.09)$ & $0.54(0.05-2.07)$ & $0.41(0.05-2.03)$ & $0.28(0.03-1.89)$ & $0.30(0.07-2.60)$ & $0.59(0.07-1.93)$ & $0.56(0.05-2,27)$ & $0.56(0.04-2.44)$ & $0.39(0.07-2.26)$ & $0.38(0.05-1.49)$ \\
\hline CD4 $4^{+}$TGF- $\beta^{+}(\%)$ & $0.32(0.09-1.79)$ & $0.71^{\mathrm{a}}(0.07-3.70)$ & $0.41(0.07-1.46)$ & $0.27(0.07-1.36)^{*}$ & $0.36(0.01-1.42)^{*}$ & $0.38(0.09-1.68)^{*}$ & $0.27(0.04-1.48)$ & $0.24(0.05-1.78)$ & $0.37(0.03-0.77)$ & $0.28(0.02-0.93)$ & $0.24(0.02-1.29)$ & $0.26(0.04-1.08)$ \\
\hline
\end{tabular}

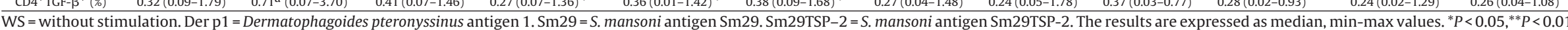
WS $=$ without stimulation. Der $\mathrm{p} 1=$ Dermatophagoides pteronyssinus antigen $1 . S \mathrm{Sm} 29=S$. mansoni

a $<<0.05$ Der $p 1$ (MA group) vs Der 1 (SA group)

Table 3

Expression of CD25, Foxp3, CD69 and CD28 by CD4 ${ }^{+}$T lymphocytes stimulated with S. mansoni antigens and the levels of IL-10 in supernatants of cell cultures from asthmatic patients.

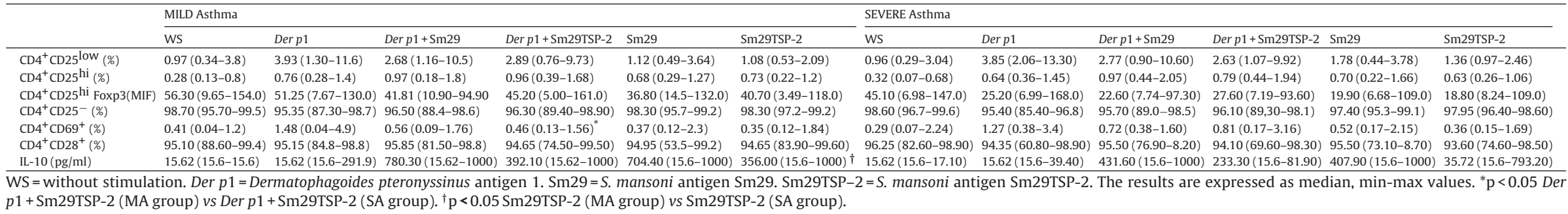


group of asthmatic subjects (Table 2). In the SA group there was no significant difference in the frequency of cells expressing the different cytokines in cultures stimulated with Der $p 1$ in the presence or absence of $S$. mansoni antigens (Table 2).

We did not observe significant difference in the frequency of $\mathrm{CD}^{+}{ }^{+} \mathrm{T}$ cells expressing the cytokines TNF, IFN- $\gamma$ and IL-17A in cultures stimulated with Der $p 1$ in the presence or absence of $S$. mansoni antigens in the HC group (data not shown).

\subsection{Expression of molecules associated with the Th2-profile after the addition of $\mathrm{S}$. mansoni antigens to the cultures}

The frequency of cells expressing the Th2-cytokines IL-5 and IL-13 and the surface receptor TSLPR, was evaluated in PBMC cultures from asthmatic patients. In the MA group there was a lower frequency of T CD $4^{+}$cells expressing IL-5 in cultures stimulated with $\operatorname{Sm} 29$ [0.19\% (0.01\%-1.2\%)], compared to the frequency in those stimulated with Der $p 1$ [0.42\% (0.06\%-3.35\%); $p<0.05$, Table 2]. Similarly, in the SA group, a lower frequency of CD $4^{+}$IL$5^{+} \mathrm{T}$ cells was observed in cultures stimulated with $\mathrm{Sm} 29[0.11 \%$ $(0.04 \%-0.53 \%)]$, compared to the frequency in cultures stimulated with Der $p 1$ [0.25\% (0.12\%-1.70\%); $\mathrm{p}<0.05$; Table 2]

There was no difference in the frequency of $\mathrm{CD} 4^{+} \mathrm{IL}-13^{+} \mathrm{T}$ cells after the addition of $S$. mansoni antigens to the cultures from the MA group (Table 2). In the SA group, however, there was a lower frequency of these cells in cultures stimulated with Sm29 [0.19\% $(0.05 \%-2.11)]$, compared to the frequency in those stimulated with Der 1 [0.45\% (0.05\%-2.29\%); $\mathrm{p}<0.05$; Table 2].

The addition of Sm29 or Sm29TSP-2 antigens did not change the expression of TSLPR in cultures stimulated with Der $p 1$ in the MA group (Table 2). However in the SA group there was an increased frequency of TSLPR expression by $\mathrm{CD}^{+} \mathrm{T}$ cells in cultures stimulated with Der p1+Sm29-TSP2 [0.62\% (0.12\%-1.5\%)], compared with the frequency in cultures stimulated with Der $p 1$ [0.25\% (0.09\%-0.91\%); $<<0.05] ; \mathrm{p}<0.05$; Table 2].

We did not observe significant difference in the frequency of $\mathrm{CD}^{+} \mathrm{T}$ cells expressing the cytokines IL-5, IL-13 and TSLPR in cultures stimulated with Der $p 1$ in the presence or absence of $S$. mansoni antigens in the HC group (data not shown).

\subsection{Regulatory molecules expressed by $C D 4^{+}$T lymphocytes in PBMC cultures of asthmatic patients}

In this study, we assessed the frequency of $C D 4^{+} \mathrm{T}$ cells expressing the regulatory markers CTLA-4, IL-10 and TGF- $\beta$ in PBMC cultures from the patients in response to $S$. mansoni antigens.

The frequency of CD4 ${ }^{+}$cells expressing CTLA- 4 and IL- 10 did not differ in cultures stimulated with Der $p 1$ in the presence or absence of the $S$. mansoni antigens in either group of asthmatic patients ( $p>0.05$; Table 2). On the other hand, the addition of Sm29TSP-2 to the cultures stimulated with Der $p 1$ [0.27\% (0.07\%-1.36\%); $\mathrm{p}<0.05]$ led to a reduction in the frequency of TCD $4^{+}$cells expressing TGF- $\beta$ in the MA group, compared with the frequency in those stimulated with Der $p 1$ alone [0.71\% (0.06\%-3.7\%); Table 2]. Cultures stimulated with Sm29 [0.36\% (0.01\%-1.42\%); p<0.05] or Sm29TSP-2 [0.38\% (0.08\%-1.68\%); $\mathrm{p}<0.05]$ showed a reduction in the frequency of cells expressing TGF- $\beta$ when compared to the frequency in cultures stimulated with Der $p 1$ alone (Table 2). In the SA group there was no significant difference in the frequency of these cells in cultures stimulated with Der $p 1$ in the presence or absence of the S. mansoni antigens (Table 2).

Regarding the frequency of $\mathrm{CD}^{+}{ }^{+} \mathrm{T}$ cells expressing TGF- $\beta$, it was higher in the group of individuals with mild asthma $[0.71(0.07-3.70)]$ than in to the group with severe asthma [0.24 (0.05-1.78), p<0.05; Table 2].
In the $\mathrm{HC}$ group the mean frequency of $\mathrm{CD} 4^{+} \mathrm{T}$ cells expressing CTLA-4, IL-10 and TGF- $\beta$ did not differs in cultures stimulated with Der $p 1$ in the presence or absence of S. mansoni antigens (data not shown).

\subsection{IL-10 levels in supernatant of PBMC cultures after the} addition of $S$. mansoni antigens

Since there was no difference in the IL-10 expression by $\mathrm{CD} 4^{+}$ $\mathrm{T}$ lymphocytes, we evaluated the levels of this cytokine in PBMC supernatants from the two different groups of asthmatic patients.

In the MA group, the addition of $\operatorname{Sm} 29[780.3 \mathrm{pg} / \mathrm{mL}$ (15.6-1000)] or Sm29TSP-2 antigens [392 pg/mL (15.6-1000)] to the cultures stimulated with Der $p 1$ resulted in increased levels of IL-10, compared to the levels in cultures stimulated with Der $p 1$ alone [15.6 pg/mL (15.6-291); $\mathrm{p}<0.001$; Fig. 5A]. The levels of IL-10 were also greater in cultures stimulated with Sm29 [704 pg/mL (15.6-1000)] or Sm29TSP-2 [356 pg/mL (15.6-1000)], when compared to the levels of those stimulated with Der $p 1$ $(\mathrm{p}<0.001)$. Additionally, all cultures stimulated with $S$. mansoni antigens, independent of the presence of Der 1 , showed an increase in IL-10 levels, compared to the levels in WS cultures $[15.6 \mathrm{pg} / \mathrm{mL}$ (15.6-15.6) p <0.01, Fig. 5A].

In $\mathrm{SA}$ group, it was observed that in the cultures stimulated with Der $p 1+\operatorname{Sm} 29$ [432 pg/mL (15.6-1000)] or Der $p 1+$ Sm29TSP-2 [233 pg/mL (15.6-982)] showed higher levels of IL-10 compared to the levels in cultures stimulated with Der p1 [15.6 pg/mL (15.6-139); $\mathrm{p}<0.001$; Fig. 4B]. There was also a higher production of IL-10 in cultures stimulated with Sm29 alone [408 pg/mL (15.6-1000); $\mathrm{p}<0.001]$ or Sm29TSP-2 alone [36 pg/mL (15.6-793.2); $\mathrm{p}<0.01$ ], compared to the levels in those stimulated with Der $p 1$. Additionally, in cultures stimulated with $S$. mansoni antigens independently of the presence of Der $p 1$, there was a higher levels of IL-10 when compared to the levels in WS cultures [15.6 pg/mL (15.6-317); $\mathrm{p}<0.001$; Fig. 5B].

In the HC group there was an increase in IL-10 levels in supernatants from cultures stimulated Der $p 1+\operatorname{Sm} 29[703 \mathrm{pg} / \mathrm{mL}$ (15.6-1000)], and Sm29 [657 pg/mL (15.6-1000)] compared to the levels in cultures stimulated with Der $p 1$ alone $[15.6 \mathrm{pg} / \mathrm{mL}$ (15.6-55); $\mathrm{p}<0.05$; Fig. 5C].

The levels of IL-10 in supernatants of PBMC cultures stimulated with Sm29TSP-2 was higher in individuals with mild asthma [356.00 (15.6-1000.00) than in those with severe asthma [35.72 (15.6-793.20), $\mathrm{p}<0.05$; Table 3].

\section{Discussion}

This study aimed to evaluate the in vitro potential of S. mansoni antigens to modulate the inflammatory response of blood mononuclear cells from subjects with asthma. Several studies have associated the expression of the CD25 molecule, which is the $\alpha$ chain of the IL-2 receptor, with the phenotype of natural regulatory $\mathrm{T}$ cells derived from the thymus. These cells are responsible for important mechanisms of immune self-tolerance and control of the immune response. Therefore, a deficiency in these cells is associated with the development of autoimmune disorders (Baecher-Allan et al., 2001; Crispin et al., 2003; Ehrenstein et al., 2004; Kim et al., 2007; Sakaguchi et al., 1995)

The present study found that the addition of Sm29TSP-2 and Sm29 antigens to PBMC cultures from patients with mild or severe asthma increased the frequency of $\mathrm{CD} 4^{+} \mathrm{CD} 25^{\mathrm{hi}} \mathrm{T}$ lymphocytes, reduced the frequency of $C D 4^{+} \mathrm{CD} 25^{\text {low }} \mathrm{T}$ cells and increased the frequency of $\mathrm{CD} 4^{+} \mathrm{CD} 25^{\text {neg }} \mathrm{T}$ cells compared to unstimulated cultures. The cultures stimulated with Der $p 1$ alone also increased frequency of $\mathrm{CD} 4^{+} \mathrm{CD} 25^{\mathrm{hi}} \mathrm{T}$ lymphocytes, however this increase 
MILD ASTHMA

A

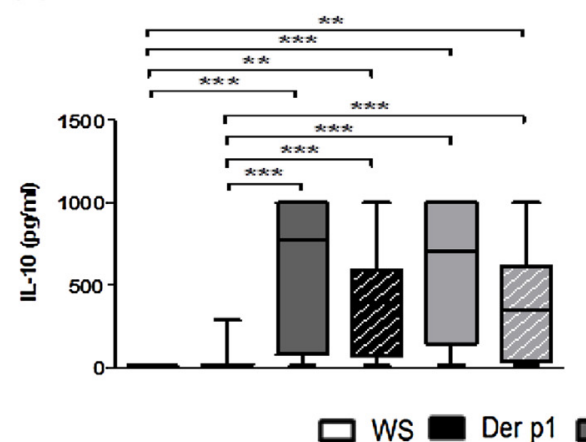

SEVERE

ASTHMA

$\mathrm{B}$

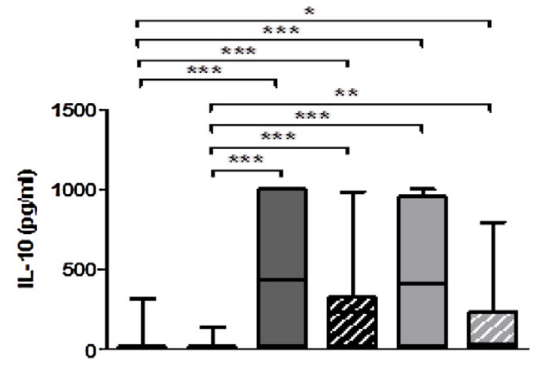

HEALTHY

CONTROLS
C

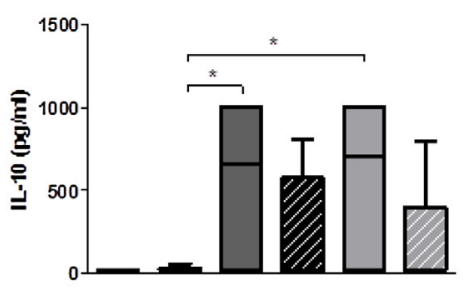

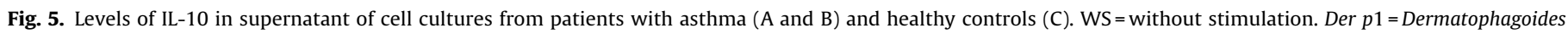

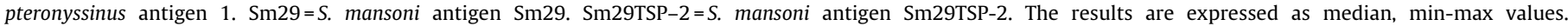
${ }^{*} P<0.05,{ }^{* *} P<0.01$, and ${ }^{* * *} P<0.001$, Kruskal-Wallis test.

was also accompanied by an increase in $\mathrm{CD} 4^{+} \mathrm{CD} 25^{\text {low }}$. Important, therefore, was the fact that the addition of Sm29 or Sm29TSP-2 to the cultures increased the frequency of CD25 high cells, a marker of $\mathrm{T}$ regulatory cell, and different to the observed when Der $p 1$ alone was added, reduced the frequency of $\mathrm{CD} 25^{\text {low }}$ cells. It suggests that the increase of $\mathrm{CD} 25^{\text {high }}$ cells in response to Der 1 does not result in down modulation of activated T cells. Indeed, one of the hypothesis to explain the existing inflammatory response in asthma and other immune-based diseases is the absence or dysfunction of regulatory T cells.

Studies have shown that individuals with asthma and allergic rhinitis have a deficiency in regulatory $\mathrm{CD} 4^{+} \mathrm{CD} 25^{\text {hi }} \mathrm{T}$ cells in their peripheral blood compared to healthy subjects (Pietruczuk et al., 2012; Rojas-Ramos et al., 2015; Stelmaszczyk-Emmel et al., 2013). Further, the bronchoalveolar lavage fluid from asthmatic children has been shown to have a reduced frequency of $\mathrm{CD} 4^{+} \mathrm{CD} 25^{\mathrm{hi}} \mathrm{T}$ cells compared to the frequency in children without asthma, and this frequency is even lower in untreated children (Hartl et al., 2007). Moreover, $\mathrm{CD} 4^{+} \mathrm{CD} 25^{\text {hi }} \mathrm{T}$ cells are able to suppress the allergic response of airway inflammation in an ovalbumin-induced mouse model of asthma (Xia et al., 2006).

There was no significant difference in the frequency of $\mathrm{CD} 4^{+} \mathrm{CD} 25^{\text {hi }} \mathrm{T}$ cells expressing Foxp3 after addition of the S. mansoni antigens. In an experimental model of ovalbumin-induced asthma, the regulation of the exacerbated inflammatory immune response observed by immunization with the Sm29 antigen was not dependent on Foxp3 (Cardoso et al., 2010). It suggests that there are other mechanisms associated to the regulatory property of Sm29antigen.

In the present study the effect of Sm29 and Sm29TSP-2 antigens on lymphocyte activation status was also evaluated. The addition of $\mathrm{Sm} 29$ was shown to reduce the frequency of $\mathrm{CD} 4^{+} \mathrm{CD} 69^{+} \mathrm{T}$ cells in cultures stimulated with Der $p 1$ in subjects with severe asthma. This reduction was also observed upon the addition of Sm29 or Sm29TSP-2 to cultures from the group of individuals with mild asthma, suggesting that these antigens have the ability to reduce the activation of $\mathrm{CD} 4^{+} \mathrm{T}$ cells in response to an allergen. In the cultures stimulated with Der $p 1$ alone, there was an increase in the frequency of $\mathrm{CD}^{+} \mathrm{T}$ lymphocytes expressing CD69 in cultures from patients with severe or mild asthma.

Studies have shown that the development of airway hyperresponsiveness induced by ovalbumin in mice is associated with an increase in the number of $\mathrm{CD} 4^{+} \mathrm{CD}_{6} 9^{+} \mathrm{T}$ lymphocytes in the airways (Zosky et al., 2009). CD69-deficient mice have been shown to have a significant reduction in their Th2 response and in the migration of lymphocytes into the lung (Miki-Hosokawa et al., 2009). Furthermore, both the peripheral blood and sputum of patients with asthma have a high number of $\mathrm{CD}^{2} 9^{+}$lymphocytes and this number is increased after stimulation by an allergen (Lourenco et al., 2009; Pelikan 2014).

In the group of individuals with mild asthma, we observed that the addition of Sm29TSP-2 to cultures stimulated with Der $p 1$ led to a reduction in the proportion of $\mathrm{CD} 4^{+} \mathrm{T}$ cells expressing inflammatory cytokines IFN- $\gamma$ and TNF.

Studies on the role of IFN- $\gamma$ in asthma have shown an increase in this cytokine in the sputum of patients with asthma compared to that in non-asthmatics. The association of IFN- $\gamma$ with disease severity has also been shown (Cho et al., 2005). The role of this cytokine in the immunopathogenesis of asthma in the murine model is highly controversial. Mice deficient in the IFN- $\gamma$ receptor show a perpetuation of the inflammatory Th2 response along with persistent eosinophilic inflammation (Coyle et al., 1996).

TNF is another cytokine widely involved in the inflammatory process observed in asthma patients, and studies have associated this cytokine with severe and refractory asthma (Berry et al., 2006; Thomas and Heywood, 2002; Thomas et al., 1995). Treatment of asthmatic individuals with a TNF antagonist prevents exacerbations of the disease (Berry et al., 2006; Erin et al., 2006; Morjaria et al., 2008).

Previous studies have demonstrated the ability of S. mansoni infection or its antigens (including Sm29), to reduce the production of Th2 cytokines in a murine model of airway inflammation and in PBMC cultures from asthmatic patients (Araujo et al., 2004; Cardoso et al., 2010; Cardoso et al., 2011). In the present study, we observed a lower frequency of $\mathrm{CD} 4^{+} \mathrm{T}$ cells expressing IL- 5 and IL13 in cultures from subjects with severe asthma stimulated with Sm29, compared to the frequency in cultures stimulated with only Der $p 1$. This reduction was not observed after the addition of Sm29 to cultures stimulated with Der $p 1$. In the mild asthma group, there was also a reduction in the frequency of $\mathrm{CD} 4^{+} \mathrm{IL}_{-} 5^{+} \mathrm{T}$ cells in cultures stimulated with $\operatorname{Sm} 29$, compared to cultures stimulated with Der $p 1$ alone.

These findings agree with previous studies, which have demonstrated the ability of Sm29 and other antigens of S. mansoni to reduce the production of IL-5 in PBMC cultures from asthmatics individuals (Cardoso et al., 2011). Additionally, this antigen has been shown to down-modulate the allergic immune response in an experimental model of asthma, decreasing the production of the Th2 cytokines IL- 4 and IL-5, the levels of specific serum IgE and 
of eosinophil peroxidase in bronchoalveolar lavage fluid (Cardoso et al., 2010).

The literature has described cytokines, such as IL-33, TSLP and IL-25, that act to maintain the Th2 response (Ballantyne et al., 2007; Kondo et al., 2008; Ying et al., 2008; Ying et al., 2005). In the present study, the addition of Sm29TSP-2 to the cultures stimulated with Der $p 1$ from the group of patients with severe asthma led to an increase in the frequency of $\mathrm{CD} 4^{+} \mathrm{T}$ lymphocytes expressing TSLP receptors. TSLP has been associated with the initiation and progression of the allergic inflammation observed in asthma, acting in synergy with IL-33 and IL-25 to support the Th2 response (Saenz et al., 2008; Ying et al., 2008; Ying et al., 2005).

The effect of $S$. mansoni antigens on the expression of molecules associated with the regulation of immune response, was also assessed in this study. In the group of patients with mild asthma, the addition of Sm29TSP-2 to cultures stimulated with Der $p 1$ led to a reduction in the frequency of $\mathrm{CD} 4^{+} \mathrm{TGF}-\beta^{+}$, which was also observed in cultures stimulated with Sm29 alone or Sm29TSP-2 alone. Although considered to be a regulatory cytokine, several studies have consistently associated TGF- $\beta$ with the pathogenesis of asthma, because it is associated with the fibrotic remodeling process of airway epithelium that results in loss of lung function (Al-Alawi et al., 2014; Fichtner-Feigl et al., 2006; Itoigawa et al., 2015; Lee et al., 2001; Xu et al., 2003). Furthermore, there are data showing high levels of TGF- $\beta$ in the bronchoalveolar lavage fluid and bronchial biopsies from individuals with asthma (Kokturk et al., 2003; Redington et al., 1997).

IL-10 has been described as a key cytokine in the inhibition of inflammatory response in asthma. It suppresses airway hyperresponsiveness, epithelial hyperplasia, eosinophilia and airway neutrophilia in an experimental model of asthma (Akbari et al., 2001; Nabe et al., 2012; Oh et al., 2002; Tournoy et al., 2000). In humans it has been reported that subjects with asthma have low levels of IL-10 in both serum and bronchoalveolar lavage fluid. They have also been show to have a decreased production of this cytokine in PBMC cultures when compared to production in healthy individuals (Borish et al., 1996; Gupta et al., 2014; Raeiszadeh Jahromi et al., 2014).

In the present study, the addition of Sm29 or Sm29TSP-2 led to an increase in the levels of IL-10 in PBMC cultures stimulated with Der $p 1$ in the group from individuals with severe asthma. The same effect was observed in cultures from the group with mild asthma. These findings agree with our previous studies demonstrating that patients with asthma infected with S. mansoni and other helminths have an increased in vitro production of IL-10 and a decreased production of Th2 cytokines, in response to Der $p 1$, when compared to the production in uninfected asthmatic patients (Araujo et al., 2004). Moreover, in our previous studies, S. mansoni antigens, including Sm29, they were able to induce IL-10 production by PBMCs from uninfected asthmatic patients (Cardoso et al., 2006a,b; Cardoso et al., 2011). These antigens were also able to induce IL-10 production in vitro in other disease models, such leishmaniasis and HTLV-1 infection (Lima et al., 2013; Lopes et al., 2014).

When we compared the two groups of asthmatic individuals we did not observe significant differences in the levels of IL-10 in response to $S$. mansoni antigens in cultures stimulated with the allergen Der $p 1$. The find of higher levels of IL-10 in cultures stimulated with Sm29TSP-2 alone in the MA group compared to SA group was an isolated finding and does not appear to be sufficient to state that this antigen benefits one or other group. Indeed, the most cell markers evaluated in this study showed a similar pattern between groups.

The increase in the levels of IL-10 in the supernatant of cultures stimulated with Der $p 1+$ Sm29 and Der $p 1+$ Sm29TSP-2 was not accompanied by the increased expression of this cytokine in lymphocytes, suggesting the existence of other cell sources of IL-
10. Previously, Cardoso et al. (2011) showed that monocytes and B lymphocytes of patients with mild asthma produced high levels of IL-10 after PBMC stimulation with Sm29.

Subjects with severe asthma were receiving inhaled corticosteroids at medium to high doses. Although such medications are directly active in the airway mucosa, there may be some small systemic bioavailability and effects. Therefore we cannot rule out the possibility some observations on the ex-vivo behavior of their PBMC might bear some influence of these medications. However, it would be unethical to withdraw treatment of patients with severe asthma for the purpose of the study.

Our results demonstrate that $S$. mansoni antigens, Sm29 and Sm29TSP-2, were able to down-modulate the in vitro inflammatory asthma response by reducing the levels of activation markers in T lymphocytes, reducing the expression of Th1 and Th2-type cytokines and inducing IL-10 production. Thus, these results suggest that the use of parasite antigens is promising in the development of strategies for controlling the dysregulated immune response that occurs with asthma.

\section{Conflict of interests}

There is no conflict of interests.

\section{Funding}

Alvaro A. Cruz was awarded a grant to contitute Nucleo de Excelência em Asma, Universidade Federal da Bahia from CNPq/FAPESB (Edital 020/2009 - PRONEX - 6353 - PNX0018/2009). An additional grant was obtained by an investigator initiated proposal supported by Trust in Science, a Glaxo SmithKline's programme.

\section{Acknowledgments}

The authors would like to thanks to Dr. Ila Muniz for the assistance, to Juliana Viana, Paula Almeida and Aline Lima for their support, A. Cruz, E. Carvalho, L. Cardoso, S. C. Oliveira and M.I. Araujo are investigators supported by The Conselho Nacional de Desenvolvimento Científico e Tecnológico (CNPq).

\section{References}

Akbari, O., DeKruyff, R.H., Umetsu, D.T., 2001. Pulmonary dendritic cells producing IL-10 mediate tolerance induced by respiratory exposure to antigen. Nat. Immunol. 2, 725-731.

Al-Alawi, M., Hassan, T., Chotirmall, S.H., 2014. Transforming growth factor beta and severe asthma: a perfect storm. Respir. Med. 108, 1409-1423.

Alcantara-Neves, N.M.S.G.B.G., Veiga de, R.V., Figueiredo, C.A., Fiaccone, R.L., Conceicao, J.S., Cruz, A.A., Rodrigues, L.C., Cooper, P.J., Pontes-de-Carvalho, L.C., Barreto, M.L., 2014. Effects of helminth co-infections on atopy, asthma and cytokine production in children living in a poor urban area in Latin America. BMC Res. Notes 7, 817.

Almeida, M.C., Lima, G.S., Cardoso, L.S., Souza, R.P., Campos, R.A., Cruz, A.A., Figueiredo, J.P., Oliveira, R.R., Carvalho, E.M., Araujo, M.I., 2012. The effect of antihelminthic treatment on subjects with asthma from an endemic area of schistosomiasis: a randomized, double-blinded, and placebo-controlled trial. J. Parasitol. Res. 2012, 296856.

Antonicelli, L., Bucca, C., Neri, M., Benedetto, F., Sabbatani, P., Bonifazi, F., Eichler, H.G., Zhang, Q., Yin, D.D., 2004. Asthma severity and medical resource utilisation. Eur. Respir. J. 23, 723-729.

Araujo, M.I., Lopes, A.A., Medeiros, M., Cruz, A.A., Sousa-Atta, L., Sole, D., Carvalho, E.M., 2000. Inverse association between skin response to aeroallergens and Schistosoma mansoni infection. Int. Arch. Allergy Immunol. 123, 145-148.

Araujo, M.I., Hoppe, B., Medeiros, M., Alcantara Jr., L., Almeida, M.C., Schriefer, A. Oliveira, R.R., Kruschewsky, R., Figueiredo, J.P., Cruz, A.A., Carvalho, E.M., 2004. Impaired $\mathrm{T}$ helper 2 response to aeroallergen in helminth-infected patients with asthma. J. Infect. Dis. 190, 1797-1803.

Bafica, A.M., Cardoso, L.S., Oliveira, S.C., Loukas, A., Varela, G.T., Oliveira, R.R., Bacellar, O., Carvalho, E.M., Araujo, M.I., 2011. Schistosoma mansoni antigens alter the cytokine response in vitro during cutaneous leishmaniasis. Mem. Inst. Oswaldo Cruz 106, 856-863. 
Baecher-Allan, C.J., Brown, A., Freeman, G.J., Hafler, D.A., 2001. CD4 CD25high regulatory cells in human peripheral blood. J. Immunol. 167, 1245-1253.

Ballantyne, S.J., Barlow, J.L., Jolin, H.E., Nath, P., Williams, A.S., Chung, K.F., Sturton, G., Wong, S.H., McKenzie, A.N., 2007. Blocking IL-25 prevents airway hyperresponsiveness in allergic asthma. J. Allergy Clin. Immunol. 120, 1324-1331

Berry, M.A., Hargadon, B., Shelley, M., Parker, D., Shaw, D.E., Green, R.H., Bradding, P., Brightling, C.E., Wardlaw, A.J., Pavord, I.D., 2006. Evidence of a role of tumor necrosis factor alpha in refractory asthma. N. Engl. J. Med. 354, 697-708.

Borish, L., Aarons, A., Rumbyrt, J., Cvietusa, P., Negri, J., Wenzel, S., 1996. Interleukin-10 regulation in normal subjects and patients with asthma. J. Allergy Clin. Immunol. 97, 1288-1296.

Bousquet, J., Mantzouranis, E., Cruz, A.A., Ait-Khaled, N., Baena-Cagnani, C.E., Bleecker, E.R., Brightling, C.E., Burney, P., Bush, A., Busse, W.W., Casale, T.B., Chan-Yeung, M., Chen, R., Chowdhury, B., Chung, K.F., Dahl, R., Drazen, J.M. Fabbri, L.M., Holgate, S.T., Kauffmann, F., Haahtela, T., Khaltaev, N., Kiley, J.P., Masjedi, M.R., Mohammad, Y., O’Byrne, P., Partridge, M.R., Rabe, K.F., Togias, A., van Weel, C., Wenzel, S., Zhong, N., Zuberbier, T., 2010. Uniform definition of asthma severity, control, and exacerbations: document presented for the World Health Organization Consultation on Severe Asthma. J. Allergy Clin. Immunol. 126, 926-938.

Campolina, S.S., Araujo, M.S., Rezende, T.M., Matoso, L., Quites, H.F., Teixeira-Carvalho, A., Martins-Filho, O.A., Gazzinelli, A., Correa-Oliveira, R., 2013. Effective anthelmintic therapy of residents living in endemic area of high prevalence for Hookworm and Schistosoma mansoni infections enhances the levels of allergy risk factor anti-Der p1 IgE. Results Immunol. 5, 6-12.

Cardoso, F.C., Pacifico, R.N., Mortara, R.A., Oliveira, S.C., 2006a. Human antibody responses of patients living in endemic areas for schistosomiasis to the tegumental protein Sm29 identified through genomic studies. Clin. Exp. Immunol. 144, 382-391.

Cardoso, L.S., Oliveira, S.C., Pacifico, L.G., Goes, A.M., Oliveira, R.R., Fonseca, C.T., Carvalho, E.M. Araujo, M.I., 2006b. Schistosoma mansoni antigen-driven interleukin-10 production in infected asthmatic individuals. Mem. Inst. Oswaldo Cruz 101 (Suppl. 1), 339-343.

Cardoso, L.S., Oliveira, S.C., Goes, A.M., Oliveira, R.R., Pacifico, L.G., Marinho, F.V., Fonseca, C.T., Cardoso, F.C., Carvalho, E.M., Araujo, M.I., 2010. Schistosoma mansoni antigens modulate the allergic response in a murine model of ovalbumin-induced airway inflammation. Clin. Exp. Immunol.

Cardoso, L.S., Oliveira, S.C., Souza, R.P., Góes, A.M., Oliveira, R.R., Alcântara, L.M., Almeida, M.C., Cravalho, E.M., Araújo, M.I., 2011. Schistosoma mansoni antigens modulate allergic response In vitro in cells of asthmatic individuals. Drug Dev. Res. 72, 538-548.

Cho, S.H., Stanciu, L.A., Holgate, S.T., Johnston, S.L., 2005. Increased interleukin-4, interleukin-5, and interferon-gamma in airway CD4+ and CD8+ T cells in atopic asthma. Am. J. Respir. Crit. Care Med. 171, 224-230.

Cooper, P.J., Chico, M.E., Rodrigues, L.C., Ordonez, M., Strachan, D., Griffin, G.E., Nutman, T.B., 2003. Reduced risk of atopy among school-age children infected with geohelminth parasites in a rural area of the tropics. J. Allergy Clin. Immunol. 111, 995-1000.

Coyle, A.J., Tsuyuki, S., Bertrand, C., Huang, S., Aguet, M., Alkan, S.S., Anderson, G.P., 1996. Mice lacking the IFN-gamma receptor have impaired ability to resolve a lung eosinophilic inflammatory response associated with a prolonged capacity of T cells to exhibit a Th2 cytokine profile. J. Immunol. 156, 2680-2685.

Crispin, J.C., Martinez, A., Alcocer-Varela, J., 2003. Quantification of regulatory T cells in patients with systemic lupus erythematosus. J. Autoimmun. 21, 273-276.

Ehrenstein, M.R., Evans, J.G., Singh, A., Moore, S., Warnes, G., Isenberg, D.A., Mauri, C., 2004. Compromised function of regulatory T cells in rheumatoid arthritis and reversal by anti-TNFalpha therapy. J. Exp. Med. 200, 277-285

Erin, E.M., Leaker, B.R., Nicholson, G.C., Tan, A.J., Green, L.M., Neighbour, H., Zacharasiewicz, A.S., Turner, J., Barnathan, E.S., Kon, O.M., Barnes, P.J., Hansel, T.T., 2006. The effects of a monoclonal antibody directed against tumor necrosis factor-alpha in asthma. Am. J. Respir. Crit. Care Med. 174, 753-762.

Fichtner-Feigl, S., Strober, W., Kawakami, K., Puri, R.K., Kitani, A., 2006. IL-13 signaling through the IL-13alpha2 receptor is involved in induction of TGF-beta1 production and fibrosis. Nat. Med. 12, 99-106.

Figueiredo, J.P., Oliveira, R.R., Cardoso, L.S., Barnes, K.C., Grant, A.V., Carvalho, E.M., Araujo, M.I., 2012. Adult worm-specific IgE/IgG4 balance is associated with low infection levels of Schistosoma mansoni in an endemic area. Parasite Immunol. 34, 604-610

Franco, R., Nascimento, H.F., Cruz, A.A., Santos, A.C., Souza-Machado, C., Ponte, E.V., Souza-Machado, A., Rodrigues, L.C., Barreto, M.L., 2009. The economic impact of severe asthma to low-income families. Allergy 64, 478-483.

Gangi, E., Vasu, C., Cheatem, D., Prabhakar, B.S., 2005. IL-10-producing CD4 + CD25+ regulatory $T$ cells play a critical role in granulocyte-macrophage colony-stimulating factor-induced suppression of experimental autoimmune thyroiditis. J. Immunol. 174, 7006-7013.

Gupta, A., Dimeloe, S., Richards, D.F., Chambers, E.S., Black, C., Urry, Z., Ryanna, K., Xystrakis, E., Bush, A., Saglani, S., Hawrylowicz, C.M., 2014. Defective IL-10 expression and in vitro steroid-induced IL-17A in paediatric severe therapy-resistant asthma. Thorax 69, 508-515.

Hagel, I., Lynch, N.R., DiPrisco, M.C., Lopez, R.I., Garcia, N.M., 1993. Allergic reactivity of children of different socioeconomic levels in tropical populations Int. Arch. Allergy Immunol. 101, 209-214.

Hartl, D., Koller, B., Mehlhorn, A.T., Reinhardt, D., Nicolai, T., Schendel, D.J., Griese, M., Krauss-Etschmann, S., 2007. Quantitative and functional impairment of pulmonary CD4 + CD25hi regulatory T cells in pediatric asthma. J. Allergy Clin. Immunol. 119, 1258-1266.

Hekking, P.P., Wener, R.R., Amelink, M., Zwinderman, A.H., Bouvy, M.L., Bel, E.H., 2014. The prevalence of severe refractory asthma. J. Allergy Clin. Immunol. 135, 896-902.

Hoffman, W.A., Pons, J.A., Janer, J.L., 1934. Sedimentation concentration method in Schistosomiasis mansoni. Publ. Health Trop. Med. 9, 283-298.

Itoigawa, Y., Harada, N., Harada, S., Katsura, Y., Makino, F., Ito, J., Nurwidya, F., Kato, M., Takahashi, F., Atsuta, R., Takahashi, K., 2015. TWEAK enhances TGF-beta-induced epithelial-mesenchymal transition in human bronchial epithelial cells. Respir. Res. 16, 48.

Kim, J.M., Rasmussen, J.P., Rudensky, A.Y., 2007. Regulatory T cells prevent catastrophic autoimmunity throughout the lifespan of mice. Nat. Immunol. 8, 191-197.

Kokturk, N., Tatlicioglu, T., Memis, L., Akyurek, N., Akyol, G., 2003. Expression of transforming growth factor beta1 in bronchial biopsies in asthma and COPD. J. Asthma 40, 887-893.

Kondo, Y., Yoshimoto, T., Yasuda, K., Futatsugi-Yumikura, S., Morimoto, M., Hayashi, N., Hoshino, T., Fujimoto, J., Nakanishi, K., 2008. Administration of IL-33 induces airway hyperresponsiveness and goblet cell hyperplasia in the lungs in the absence of adaptive immune system. Int. Immunol. 20, 791-800.

Layland, L.E., Straubinger, K., Ritter, M., Loffredo-Verde, E., Garn, H., Sparwasser, T., Prazeres da Costa, C., 2013. Schistosoma mansoni-mediated suppression of allergic airway inflammation requires patency and Foxp3+ Treg cells. PLoS Negl. Trop. Dis. 7, e2379.

Lee, C.G., Homer, R.J., Zhu, Z., Lanone, S., Wang, X., Koteliansky, V., Shipley, J.M., Gotwals, P., Noble, P., Chen, Q., Senior, R.M., Elias, J.A., 2001. Interleukin-13 induces tissue fibrosis by selectively stimulating and activating transforming growth factor beta(1). J. Exp. Med. 194, 809-821.

Lima, L.M., Santos, S.B., Oliveira, R.R., Cardoso, L.S., Oliveira, S.C., Goes, A.M., Loukas, A., Carvalho, E.M., Araujo, M.I., 2013. Schistosoma antigens downmodulate the in vitro inflammatory response in individuals infected with human $\mathrm{T}$ cell lymphotropic virus type 1. Neuroimmunomodulation 20, 233-238.

Lopes, D.M., Fernandes, J.S., Cardoso, T.M., Bafica, A.M., Oliveira, S.C., Carvalho, E.M., Araujo, M.I., Cardoso, L.S., 2014. Dendritic cell profile induced by Schistosoma mansoni antigen in cutaneous leishmaniasis patients. BioMed Res. Int., 743069

Lourenco, O., Mafalda Fonseca, A., Taborda-Barata, L., 2009. T cells in sputum of asthmatic patients are activated independently of disease severity or control. Allergol. Immunopathol. (Madr.) 37, 285-292.

Lynch, N.R., Lopez, R.I., Di Prisco-Fuenmayor, M.C., Hagel, I., Medouze, I., Viana, G., Ortega, C., Prato, G., 1987. Allergic reactivity and socio-economic level in a tropical environment. Clin. Allergy 17, 199-207.

Lynch, N.R., Hagel, I., Perez, M., Di Prisco, M.C., Lopez, R., Alvarez, N., 1993. Effect of anthelmintic treatment on the allergic reactivity of children in a tropical slum. J. Allergy Clin. Immunol. 92, 404-411.

Medeiros Jr., M., Figueiredo, J.P., Almeida, M.C., Matos, M.A., Araujo, M.I., Cruz, A.A Atta, A.M., Rego, M.A., de Jesus, A.R., Taketomi, E.A., Carvalho, E.M., 2003. Schistosoma mansoni infection is associated with a reduced course of asthma. J. Allergy Clin. Immunol. 111, 947-951.

Medeiros, M., Almeida Jr., M.C., Figueiredo, J.P., Atta, A.M., Mendes, C.M., Araujo, M.I., Taketomi, E.A., Terra, S.A., Silva, D.A., Carvalho, E.M., 2004. Low frequency of positive skin tests in asthmatic patients infected with Schistosoma mansoni exposed to high levels of mite allergens. Pediatr. Allergy Immunol. 15, $142-147$.

Miki-Hosokawa, T., Hasegawa, A., Iwamura, C., Shinoda, K., Tofukuji, S., Watanabe, Y., Hosokawa, H., Motohashi, S., Hashimoto, K., Shirai, M., Yamashita, M., Nakayama, T., 2009. CD69 controls the pathogenesis of allergic airway inflammation. J. Immunol. 183, 8203-8215.

Moore, W.C., Bleecker, E.R., Curran-Everett, D., Erzurum, S.C., Ameredes, B.T., Bacharier, L., Calhoun, W.J., Castro, M., Chung, K.F., Clark, M.P., Dweik, R.A. Fitzpatrick, A.M., Gaston, B., Hew, M., Hussain, I., Jarjour, N.N., Israel, E., Levy, B.D., Murphy, J.R., Peters, S.P., Teague, W.G., Meyers, D.A., Busse, W.W., Wenzel S.E., 2007. Characterization of the severe asthma phenotype by the national heart, lung, and blood institute's severe asthma research program. J. Allergy Clin. Immunol. 119, 405-413.

Morjaria, J.B., Chauhan, A.J., Babu, K.S., Polosa, R., Davies, D.E., Holgate, S.T., 2008. The role of a soluble TNFalpha receptor fusion protein (etanercept) in corticosteroid refractory asthma: a double blind, randomised, placebo controlled trial. Thorax 63, 584-591.

Nabe, T., Ikedo, A., Hosokawa, F., Kishima, M., Fujii, M., Mizutani, N., Yoshino, S., Ishihara, K., Akiba, S., Chaplin, D.D., 2012. Regulatory role of antigen-induced interleukin-10, produced by CD4(+) T cells, in airway neutrophilia in a murine model for asthma. Eur. J. Pharmacol. 677, 154-162.

O’Neill, S., Sweeney, J., Patterson, C.C., Menzies-Gow, A., Niven, R., Mansur, A.H., Bucknall, C., Chaudhuri, R., Thomson, N.C., Brightling, C.E., O'Neill, C.E., Heaney, L.G., 2015. The cost of treating severe refractory asthma in the UK: an economic analysis from the British Thoracic Society Difficult Asthma Registry. Thorax 70, 376-378.

Oh, J.W., Seroogy, C.M., Meyer, E.H., Akbari, O., Berry, G., Fathman, C.G., Dekruyff, R.H., Umetsu, D.T., 2002. CD4 T-helper cells engineered to produce IL-10 prevent allergen-induced airway hyperreactivity and inflammation. J. Allergy Clin. Immunol. 110, 460-468.

Okita, R., Yamaguchi, Y., Ohara, M., Hironaka, K., Okawaki, M., Nagamine, I., Ikeda, T., Emi, A., Hihara, J., Okada, M., 2009. Targeting of CD4 + CD25high cells while preserving CD4 + CD25low cells with low-dose chimeric anti-CD25 antibody in adoptive immunotherapy of cancer. Int. J. Oncol. 34, 563-572. 
Oliveira, R.R., Gollob, K.J., Figueiredo, J.P., Alcantara, L.M., Cardoso, L.S., Aquino, C.S., Campos, R.A., Almeida, M.C., Carvalho, E.M., Araujo, M.I., 2009. Schistosoma mansoni infection alters co-stimulatory molecule expression and cell activation in asthma. Microbes Infect. 11, 223-229.

Pacifico, L.G., Marinho, F.A., Fonseca, C.T., Barsante, M.M., Pinho, V., Sales Junior, P.A., Cardoso, L.S., Araujo, M.I., Carvalho, E.M., Cassali, G.D., Teixeira, M.M., Oliveira, S.C., 2009. Schistosoma mansoni antigens modulate experimental allergic asthma in a murine model: a major role for CD4+CD25+ Foxp3+ T cells independent of interleukin-10. Infect Immun. 77, 98-107.

Pelikan, Z., 2014. Expression of surface markers on the blood cells during the delayed asthmatic response to allergen challenge. Allergy Rhinol. (Providence) 5, 96-109.

Pietruczuk, M., Eusebio, M., Kraszula, L., Kupczyk, M., Kuna, P., 2012. Phenotypic characterization of ex vivo CD4 + CD25highCD127low immune regulatory T cells in allergic asthma: pathogenesis relevance of their FoxP3, GITR, CTLA-4 and FAS expressions. J. Biol. Regul. Homeost. Agents 26, 627-639.

Pinheiro, C.S., Ribeiro, A.P.D., Cardoso, F.C., Martins, V.P., Figueiredo, B.C.P., Assis, N.R.G., Morais, S.B., Caliari, M.V., Loukas, A., Oliveira, S.C., 2014. A multivalent chimeric vaccine composed of Schistosoma mansoni SmTSP-2 and Sm29 was able to induce protection against infection in mice. Parasite Immunol. 36, 303-312.

Pontoux, C., Banz, A., Papiernik, M., 2002. Natural CD4 CD25(+) regulatory T cells control the burst of superantigen-induced cytokine production: the role of IL-10. Int. Immunol. 14, 233-239.

Raeiszadeh Jahromi, S., Mahesh, P.A., Jayaraj, B.S., Madhunapantula, S.R., Holla, A.D. Vishweswaraiah, S., Ramachandra, N.B., 2014. Serum levels of IL-10, IL-17F and IL-33 in patients with asthma: a case-control study. J. Asthma 51, 1004-1013.

Redington, A.E., Madden, J., Frew, A.J., Djukanovic, R., Roche, W.R., Holgate, S.T., Howarth, P.H., 1997. Transforming growth factor-beta 1 in asthma. Measurement in bronchoalveolar lavage fluid. Am. J. Respir. Crit. Care Med. 156, 642-647.

Rojas-Ramos, E., Martinez-Jimenez, N.E., Verdejo-Hernandez, B., Vazquez, G., 2015. Expression of CD152 and CD137 on T regulatory cells in rhinitis and bronchial asthma patients. Rev. Alerg. Mex. 62, 118-124.

Saenz, S.A., Taylor, B.C., Artis, D., 2008. Welcome to the neighborhood: epithelial cell-derived cytokines license innate and adaptive immune responses at mucosal sites. Immunol. Rev. 226, 172-190.

Sakaguchi, S., Sakaguchi, N., Asano, M., Itoh, M., Toda, M., 1995. Immunologic self-tolerance maintained by activated T cells expressing IL-2 receptor alpha-chains (CD25). Breakdown of a single mechanism of self-tolerance causes various autoimmune diseases. J. Immunol. 155, 1151-1164.

Santos, L.A., Oliveira, M.A., Faresin, S.M., Santoro, I.L., Fernandes, A.L., 2007. Direct costs of asthma in Brazil: a comparison between controlled and uncontrolled asthmatic patients. Braz. J. Med. Biol. Res. 40, 943-948.

Simpson, A.J., Hagan, P., Hackett, F., Omer Ali, P., Smithers, S.R., 1990. Epitopes expressed on very low Mr Schistosoma mansoni adult tegumental antigens conform to a general pattern of life-cycle cross-reactivity. Parasitology 100 (Pt. 1), 73-81.

Smits, H.H., Hammad, H., van Nimwegen, M., Soullie, T., Willart, M.A., Lievers, E. Kadouch, J., Kool, M., Kos-van Oosterhoud, J., Deelder, A.M., Lambrecht, B.N., Yazdanbakhsh, M., 2007. Protective effect of Schistosoma mansoni infection on allergic airway inflammation depends on the intensity and chronicity of infection. J. Allergy Clin. Immunol. 120, 932-940.

Sojka, D.K., Hughson, A., Fowell, D.J., 2009. CTLA-4 is required by CD4 + CD25+ Treg to control CD4+ T-cell lymphopenia-induced proliferation. Eur. J. Immunol. 39 1544-1551.

Souza-Atta, M.L., Araujo, M.I., D’Oliveira Junior, A., Ribeiro-de-Jesus, A., Almeida, R.P., Atta, A.M., Carvalho, E.M., 1999. Detection of specific IgE antibodies in parasite diseases. Braz. J. Med. Biol. Res. 32, 1101-1105.

Stelmaszczyk-Emmel, A., Zawadzka-Krajewska, A., Szypowska, A., Kulus, M., Demkow, U., 2013. Frequency and activation of CD4 + CD25 FoxP3+ regulatory
T cells in peripheral blood from children with atopic allergy. Int. Arch. Allergy Immunol. 162, 16-24.

Thomas, P.S., Heywood, G., 2002. Effects of inhaled tumour necrosis factor alpha in subjects with mild asthma. Thorax 57, 774-778.

Thomas, P.S., Yates, D.H., Barnes, P.J., 1995. Tumor necrosis factor-alpha increases airway responsiveness and sputum neutrophilia in normal human subjects. Am. J. Respir. Crit. Care Med. 152, 76-80.

Tournoy, K.G., Kips, J.C., Pauwels, R.A., 2000. Endogenous interleukin-10 suppresses allergen-induced airway inflammation and nonspecific airway responsiveness. Clin. Exp. Allergy 30, 775-783.

Tran, M.H., Pearson, M.S., Bethony, J.M., Smyth, D.J., Jones, M.K., Duke, M., Don, T.A., McManus, D.P., Correa-Oliveira, R., Loukas, A., 2006. Tetraspanins on the surface of Schistosoma mansoni are protective antigens against schistosomiasis. Nat. Med. 12, 835-840.

Uhlig, H.H., Coombes, J., Mottet, C., Izcue, A., Thompson, C., Fanger, A., Tannapfel, A. Fontenot, J.D., Ramsdell, F., Powrie, F., 2006. Characterization of Foxp3 + CD 4 + CD25+ and IL-10-secreting CD4 + CD25+ T cells during cure of colitis. J. Immunol. 177, 5852-5860.

Van den Biggelaar, A.H., Van Ree, R., Rodrigues, L.C., Lell, B., Deelder, A.M., Kremsner, P.G., Yazdanbakhsh, M., 2000. Decreased atopy in children infected with Schistosoma haematobium: a role for parasite-induced interleukin-10. Lancet 356, 1723-1727.

Van den Biggelaar, A.H., Lopuhaa, C., van Ree, R., van der Zee, J.S., Jans, J., Hoek, A. Migombet, B., Borrmann, S., Luckner, D., Kremsner, P.G., Yazdanbakhsh, M., 2001. The prevalence of parasite infestation and house dust mite sensitization in Gabonese schoolchildren. Int. Arch. Allergy Immunol. 126, 231-238.

Van den Biggelaar, A.H., Rodrigues, L.C., Van Ree, R., Van der Zee, J.S., Hoeksma-Kruize, Y.C., Souverijn, J.H., Missinou, M.A., Borrmann, S., Kremsner, P.G., Yazdanbakhsh, M., 2004. Long-term treatment of intestinal helminths increases mite skin-test reactivity in Gabonese schoolchildren. J. Infect. Dis 189, 892-900.

Van der Vlugt, L.E., Labuda, L.A., Ozir-Fazalalikhan, A., Lievers, E., Gloudemans, A.K., Liu, K.Y., Barr, T.A., Sparwasser, T., Boon, L., Ngoa, U.A., Feugap, E.N., Adegnika, A.A., Kremsner, P.G., Gray, D., Yazdanbakhsh, M., Smits, H.H., 2012. Schistosomes induce regulatory features in human and mouse CD1d(hi) B cells: inhibition of allergic inflammation by IL-10 and regulatory T cells. PLoS One 7, e30883.

Von Bulow, A., Kriegbaum, M., Backer, V., Porsbjerg, C., 2014. The prevalence of severe asthma and low asthma control among Danish adults. J. Allergy Clin. Immunol. Pract. 2, 759-767.

Xia, Z.W., Zhong, W.W., Xu, L.Q., Sun, J.L., Shen, Q.X., Wang, J.G., Shao, J., Li, Y.Z., Yu, S.C., 2006. Heme oxygenase-1-mediated CD4 + CD25high regulatory T cells suppress allergic airway inflammation. J. Immunol. 177, 5936-5945.

Xu, Y.D., Hua, J., Mui, A., O'Connor, R., Grotendorst, G., Khalil, N., 2003. Release of biologically active TGF-beta 1 by alveolar epithelial cells results in pulmonary fibrosis. Am. J. Physiol. Lung Cell. Mol. Physiol. 285, L527-539.

Ying, S., O’Connor, B., Ratoff, J., Meng, Q., Mallett, K., Cousins, D., Robinson, D., Zhang, G., Zhao, J., Lee, T.H., Corrigan, C., 2005. Thymic stromal lymphopoietin expression is increased in asthmatic airways and correlates with expression of Th2-attracting chemokines and disease severity. J. Immunol. 174, 8183-8190.

Ying, S., O’Connor, B., Ratoff, J., Meng, Q., Fang, C., Cousins, D., Zhang, G., Gu, S., Gao, Z., Shamji, B., Edwards, M.J., Lee, T.H., Corrigan, C.J., 2008. Expression and cellular provenance of thymic stromal lymphopoietin and chemokines in patients with severe asthma and chronic obstructive pulmonary disease. J. Immunol. 181, 2790-2798.

Zosky, G.R., Larcombe, A.N., White, O.J., Burchell, J.T., Von Garnier, C., Holt, P.G., Turner, D.J., Wikstrom, M.E., Sly, P.D., Stumbles, P.A., 2009. Airway hyperresponsiveness is associated with activated CD4+ T cells in the airways. Am. J. Physiol. Lung Cell. Mol. Physiol. 297, L373-379. 